


\section{Validatie Meyn Footpad Inspection System}

J. van Harn en I.C. de Jong

Dit onderzoek is uitgevoerd door Wageningen Livestock Research, in opdracht van en gefinancierd door het Ministerie van Economische Zaken, in het kader van het Beleidsondersteunend onderzoek thema 'Dierenwelzijn' (projectnummer BO-20-008-036).

Wageningen Livestock Research

Wageningen, september 2017

Rapport 1044 
Van Harn, J., De Jong, I.C., 2017. Validatie Meyn Footpad Inspection System. Wageningen Livestock Research, Rapport 1044 .

\section{Samenvatting NL}

Dit rapport beschrijft de resultaten van een validatie van het Meyn Footpad Inspection System, een camerasysteem om automatisch voetzoollaesies bij vleeskuikens aan de slachtlijn te beoordelen. Er gaan geluiden op dat dit camerasysteem mogelijk anders scoort dan handmatige metingen aan de slachtlijn door getrainde slachterijmedewerkers. Op verzoek van het Ministerie van Economische Zaken heeft Wageningen Livestock Research daarom een beperkte validatie van het camerasysteem uitgevoerd. Deze validatie werd uitgevoerd op één Nederlandse slachterij en omvatte twee reguliere slachtdagen. Op deze slachtdagen werd de voetzoollaesiescore van een steekproef van alle aangevoerde koppels zowel handmatig als met de camera bepaald. In dit rapport worden de resultaten van deze metingen beschreven.

\section{Summary UK}

The current report describes the results of a validation of the Meyn Footpad Inspection System, a video imaging system to score footpad lesions in broiler chickens at the slaughter plant. It was suggested that the system might assign a different score to footpad lesions compared to a trained manual scorer. Therefore, on the request of the Ministry of Economic Affairs, Wageningen Livestock Research performed a limited validation of the system during two days at a commercial plant in The Netherlands. During the validation, the footpad lesion score was determined in a sample of each flock slaughtered on that particular day, manually by a trained observer as well as by the camera system, and the results were compared. This reports describes the results of this validation.

Dit rapport is gratis te downloaden op https://doi.org/10.18174/423304 of op www.wur.nl/livestock-research (onder Wageningen Livestock Research publicaties).

\section{(C) 2017 Wageningen Livestock Research}

Postbus 338, 6700 AH Wageningen, T 03174839 53, E info.livestockresearch@wur.nl, www.wur.nl/livestock-research. Wageningen Livestock Research is onderdeel van Wageningen University \& Research.

Wageningen Livestock Research aanvaardt geen aansprakelijkheid voor eventuele schade voortvloeiend uit het gebruik van de resultaten van dit onderzoek of de toepassing van de adviezen.

Alle rechten voorbehouden. Niets uit deze uitgave mag worden vermenigvuldigd en/of openbaar gemaakt worden door middel van druk, fotokopie, microfilm of op welke wijze dan ook zonder voorafgaande toestemming van de uitgever of auteur.

De certificering volgens ISO 9001 door DNV onderstreept ons kwaliteitsniveau. Op als onze onderzoeksopdrachten zijn de Algemene Voorwaarden van de Animal Sciences Group van toepassing. Deze zijn gedeponeerd bij de Arrondissementsrechtbank Zwolle. 


\section{Inhoud}

$\begin{array}{ll}\text { Woord vooraf } & 5\end{array}$

$\begin{array}{ll}\text { Samenvatting } & 7\end{array}$

$\begin{array}{ll}1 & \text { Inleiding }\end{array}$

$\begin{array}{lll}1.1 & \text { Doelstelling } & 9\end{array}$

2

$\begin{array}{ll}\text { Methode } & 10\end{array}$

2.1 Camerasysteem $\quad 10$

2.2 Verzamelen looppoten en beelden 12

2.3 Vergelijking camera met handmatige meting 12

2.4 Dataverwerking $\quad 13$

2.4.1 Berekening correlaties 13

2.4.2 Statistische analyse 13

2.4.3 Vergelijking meten van beide voetzolen met beoordelen van alleen de $\begin{array}{ll}\text { linker- of rechter poot } & 14\end{array}$

3

$\begin{array}{ll}\text { Resultaten } & 15\end{array}$

$\begin{array}{lll}3.1 & \text { Performance camerasysteem } & 15\end{array}$

3.2 Vergelijking per scoringsklasse $\quad 16$

$\begin{array}{lll}3.3 & \text { Vergelijking voetzoollaesiescore } & 17\end{array}$

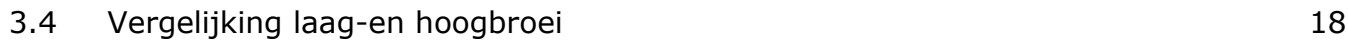

$\begin{array}{lll}3.5 & \text { Statistische analyse } & 19\end{array}$

3.6 Vergelijking meten van beide voetzolen met beoordelen van alleen de linker- of rechter poot $\quad 19$

Conclusie $\quad 24$

$\begin{array}{ll}\text { Literatuur } & 25\end{array}$

$\begin{array}{lll}\text { Bijlage } 1 \text { Software recept bij laagbroei } & 26\end{array}$

$\begin{array}{lll}\text { Bijlage } 2 & \text { Software recept bij hoogbroei } & 27\end{array}$

Bijlage 3 Scorekaart voetzoollaesies vleeskuikens versie $1.3 \quad 28$

Bijlage 4 Scores per klasse $\quad 30$

Bijlage 5 Correlatie per scoringsklasse (o.b.v. steekproef) 32

Bijlage 6 Behaalde voetzoollaesiescores per steekproef en koppelniveau 33

$\begin{array}{lll}\text { Bijlage } 7 & \text { Voetzoollaesiescores per steekproef } & 35\end{array}$

Bijlage 8 Voorbeelden van foutief gemeten beelden 36

Bijlage 9 Correlatie per scoringsklasse (o.b.v. steekproef) 38

Bijlage 10 Correlatie voetzoolaesiescore (o.b.v. steekproef) 40

$\begin{array}{lll}\text { Bijlage } 11 & \text { Statistische analyse } & 41\end{array}$ 


\section{Woord vooraf}

Meyn Food Processing Technology heeft in samenwerking met Wageningen UR in de periode tussen 2006 en 2011 een camerasysteem ontwikkeld waarmee automatisch voetzoollaesies aan de slachtlijn kunnen worden beoordeeld. Dit systeem, het Meyn Footpad Inspection System, werd tot voor kort in twee Nederlandse pluimveeslachterijen gebruikt. Er zijn echter vragen gerezen over het functioneren van het camerasysteem. Om deze reden heeft Wageningen UR Livestock Research, op verzoek van het Ministerie van Economische Zaken, opnieuw een beperkte validatie van het camerasysteem uitgevoerd analoog aan eerdere validaties welke in 2013 en 2015 zijn uitgevoerd. Dit rapport beschrijft de resultaten van de validatie.

Ingrid de Jong (projectleider) 


\section{Samenvatting}

Meyn Food Processing Technology heeft in samenwerking met Wageningen Livestock Research een camerasysteem ontwikkeld voor het automatisch meten van voetzoollaesies aan de slachtlijn. Meyn heeft de afgelopen jaren gewerkt aan de verdere ontwikkeling van dit camerasysteem. Toch zijn er in de praktijk, bij pluimveehouders en slachterijen, nog steeds twijfels met betrekking tot de correctheid van de camerametingen in vergelijking met handmatige metingen aan de slachtlijn (door getrainde medewerkers, keurmeesters of dierenartsen). Om die reden heeft het Ministerie van Economische Zaken aan Wageningen Livestock Research gevraagd het camerasysteem nogmaals te valideren.

De validatie van het camerasysteem vond plaats bij een Nederlandse pluimveeslachterij. Het systeem wordt op deze slachterij al enkele jaren gebruikt. Gedurende twee reguliere slachtdagen, maandag 20 februari 2017 en maandag 15 mei 2017, zijn metingen uitgevoerd aan het camerasysteem bij alle koppels die op die dagen werden geslacht. Op de eerste en tweede slachtdag werden er respectievelijk 7 en 11 koppels geslacht en gemeten. Een koppel is daarbij gedefinieerd als alle dieren afkomstig uit dezelfde stal die op hetzelfde moment werden afgeleverd aan de slachterij. Per koppel zijn in één of meerdere steekproeven genomen. In totaal resulteerde dat in 35 steekproeven, 20 op de eerste slachtdag en 15 op de tweede slachtdag. Per steekproef werden ongeveer 400 potenparen beoordeeld door het camerasysteem en uit deze serie werden 100 rechterpootjes handmatig beoordeeld door een getrainde Wageningen Livestock Research (WLR) beoordelaar. Een één op één vergelijking van handmatige beoordeling en camerabeoordeling was niet mogelijk door de te hoge lijnsnelheden. De vergelijking van de voetzoollaesiescores werd uitgevoerd bij zowel laag- als hoogbroei.

Op basis van deze beperkte vergelijking van de beoordeling van voetzoollaesies door het Meyn Footpad Inspection System en Wageningen Livestock Research lijkt het camerasysteem de scores van de getrainde WLR-beoordelaar goed te volgen, getuige de hoge correlatie die werd gevonden $\left(R^{2}=0,96\right)$. Koppels met zeer weinig voetzoollaesies (FPS (Footpad Score) <60) kregen van het camerasysteem een iets hogere score dan van de WLR-beoordelaar, koppels met veel voetzoollaesies (FPS >120) kregen een iets lagere score van de camera dan van de WLR-beoordelaar. De afwijking van de camera was iets groter bij hoogbroei dan bij laagbroei.

Gemiddeld over alle koppels genomen gaf het camerasysteem een iets hogere (dus slechtere) score aan een koppel dan de WLR-beoordelaar (camera vs. WLR 82 vs. 78 punten). Bij twee van de achttien koppels week de voetzoollaesiescore van het Meyn Footpad Inspection System meer dan 20 punten af van die van de WLR-beoordelaar. Het betrof hier koppels met grote maar oppervlakkige laesies, welke door de camera ten onrechte als score 2 werden aangemerkt, terwijl deze als klasse 1 laesie hadden moeten worden gekwalificeerd. Bij tien van de achttien was de afwijking in de voetzoollaesiescore van het camerasysteem ten opzichte van de WLR-beoordelaar kleiner dan 10 punten, en bij zes koppels bedroeg de afwijking tussen de 10 en 20 punten.

Concluderend, op basis van deze beperkte validatie lijkt de score van het Meyn Footpad Inspection System de score van de WLR-beoordelaar goed te volgen. De camera beoordeelde de laesies wel iets zwaarder dan de WLR-beoordelaar, waardoor gemiddeld genomen de voetzoollaesiescores bij het camerasysteem iets hoger uitvielen dan die van de WLR-beoordelaar. Dit gold met name bij koppels met geen tot geringe voetzoollaesies (FPS tussen 0 - 60). Groot voordeel van het camerasysteem ten opzichte van een handmatige meting/beoordeling is dat vrijwel alle pootjes van een koppel beoordeeld worden. Het camerasysteem was in deze zeer beperkte validatiestudie in staat om de pootjes van $99 \%$ van de aangeboden kuikens te beoordelen. Bij een handmatige beoordeling worden er conform protocol slechts 100 pootjes per koppel beoordeeld ongeacht de grootte van de koppel. De steekproef (d.w.z. waar in het koppel deze pootjes worden geselecteerd) bij een handmatige meting kan dus een groot effect hebben op de uiteindelijke voetzoollaesiescore van een koppel, omdat de mate waarin voetzoollaesies voorkomen niet altijd gelijk verdeeld is over een stal. 


\section{$1 \quad$ Inleiding}

Het Meyn Footpad Inspection System, een camerasysteem waarmee automatisch voetzoollaesies van vleeskuikens aan de slachtlijn worden beoordeeld, is sinds 2013 een toegestane methode voor het scoren van voetzoollaesies in het kader van de Vleeskuikenrichtlijn. De toelating van dit systeem is verkregen na een beperkte validatie door Wageningen Livestock Research (De Jong, 2013), waarbij de beoordeling van het camerasysteem werd getoetst aan de 'gouden standaard', dat wil zeggen een getrainde beoordelaar van Wageningen Livestock Research, die scoort aan de hand van de eerder vastgestelde classificatie voor voetzoollaesies bij vleeskuikens.

Hoewel het camerasysteem een erkende methode is om voetzoollaesies aan de slachtlijn te beoordelen, beoordeelt het grootste deel van de pluimveeslachterijen voetzoollaesies nog steeds handmatig volgens het vastgestelde protocol (De Jong et al., 2011). Een mogelijke reden voor het beperkte gebruik van het camerasysteem in Nederland is de prijs van het systeem. Echter, de pluimveesector geeft ook aan dat ze twijfelen of het systeem correct meet. Dit laatste ondanks het feit dat sinds de validatie in 2013 (De Jong, 2013) het camerasysteem verder is verbeterd.

Gezien de terugkerende discussie over de wijze waarop het camerasysteem voetzoollaesies meet, maar ook de voordelen van een camerasysteem ten opzichte van een handmatige meting, heeft het Ministerie van Economische zaken aan Wageningen Livestock Research gevraagd om nogmaals een beperkte validatie uit te voeren van de meest recente versie van het camerasysteem, analoog aan de eerder uitgevoerde beperkte validatie (De Jong, 2013).

\section{$1.1 \quad$ Doelstelling}

Vaststellen of het Meyn Footpad Inspection System voetzoollaesies scoort volgens de door Wageningen Livestock Research gehanteerde scoresystematiek (De Jong et al., 2011). 


\section{Methode}

\section{$2.1 \quad$ Camerasysteem}

De validatie van het camerasysteem is uitgevoerd bij een Nederlandse vleeskuikenslachterij. Bij deze slachterij is de meest recente versie van het camerasysteem geïnstalleerd en al langere tijd in gebruik. Voor een beschrijving van het camerasysteem verwijzen we naar De Jong et al. (2011). In figuur 2.1 wordt schematisch het camerasysteem inclusief positioneringssysteem weergegeven. Figuur 2.2 toont de camera zoals deze op de slachterij is geïnstalleerd.

Meyn heeft zowel de hardware als de software van het camerasysteem aangepast ten opzichte van het oorspronkelijke gevalideerde camerasysteem (De Jong, 2013). Deze aanpassingen waren erop gericht om de prestaties van het camerasysteem verder te verbeteren. Zo is er een positioneringssysteem aangebracht om de pootjes beter in het beeld van de camera te krijgen. Dit positioneringssysteem heeft ertoe geleid dat ruim 95 procent van alle pootjes van een koppel gemeten kunnen worden. Hetgeen ruim hoger is dan de eis van 70 procent die oorspronkelijk werd gesteld aan het camerasysteem (De Jong et al., 2011). Daarnaast is de software aangepast zodat de scores van de camera nog beter overeenkomen met die van een getrainde beoordelaar, de zogenaamde 'gouden standaard'. Hierna volgen puntsgewijs de aanpassingen aan het camerasysteem, zowel hardware- als softwarematig, sinds de laatste validatie in 2015 (De Jong en Van Harn, niet gepubliceerde gegevens).

Hardware aanpassingen:

1. Geleidestang toegevoegd, welke de pootjes overneemt van een geleidewiel. Geleidewiel voor een optimale positie van de pootjes voor een goede opname door de camera.

2. Een sproeistang met een timer om achterwand vrij te houden van verontreinigingen zoals veren en huidschilfers.

Software aanpassingen:

1. Software meer robuust gemaakt om segmentatie beter te maken.

2. Nieuwe regel toegevoegd om de voor iedereen lastige oppervlakkige laesie beter te herkennen en in goede klasse te plaatsen.

3. Nieuwe regel toegevoegd om toegedekte laesie (door huidplooien) aan rand of net binnen meetgebied te herkennen en in juiste klasse te plaatsen.

4. Aanpassing van kleurinstellingen om zo detectie en herkenning laesie te verbeteren en minder gevoelig te maken voor hoge relatieve vochtigheid in directe omgeving.

5. Aanpassing software om de toegevoegde geleidestang te negeren.

6. In voorbereiding, gereed augustus/september 2017: een automatische herkenning van de beeldkwaliteit en signalering van achteruitgang van de kwaliteit (bijvoorbeeld door kalkaanslag op het venster). 


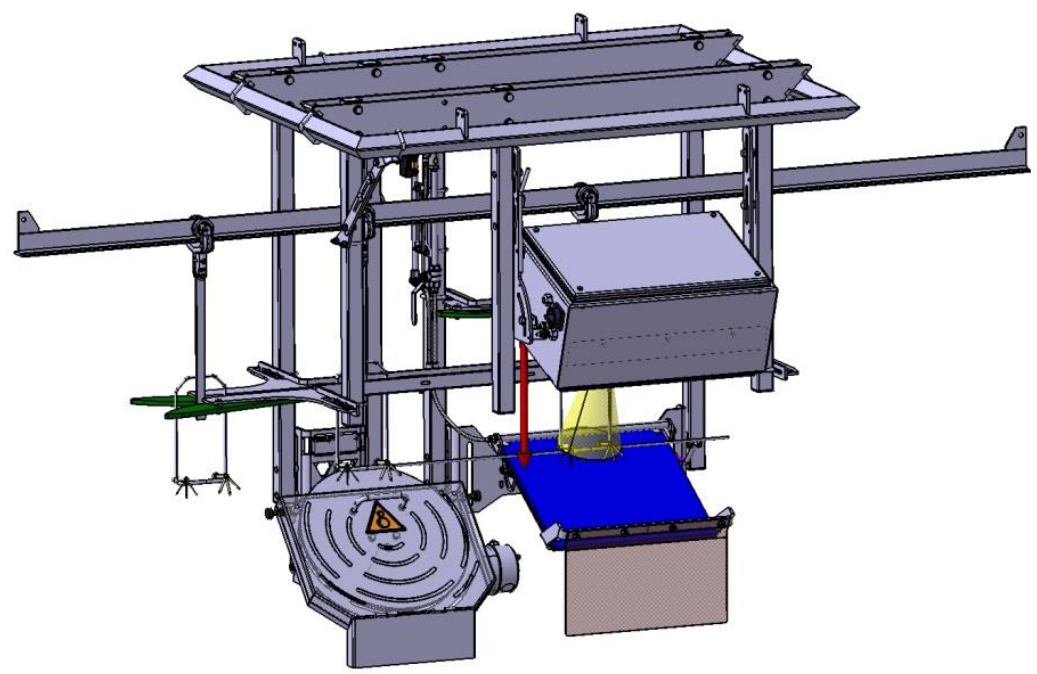

Figuur 2.1 Schematische weergave cameraopstelling incl. positioneringsunit aan de slachtlijn vlak voor de camera.

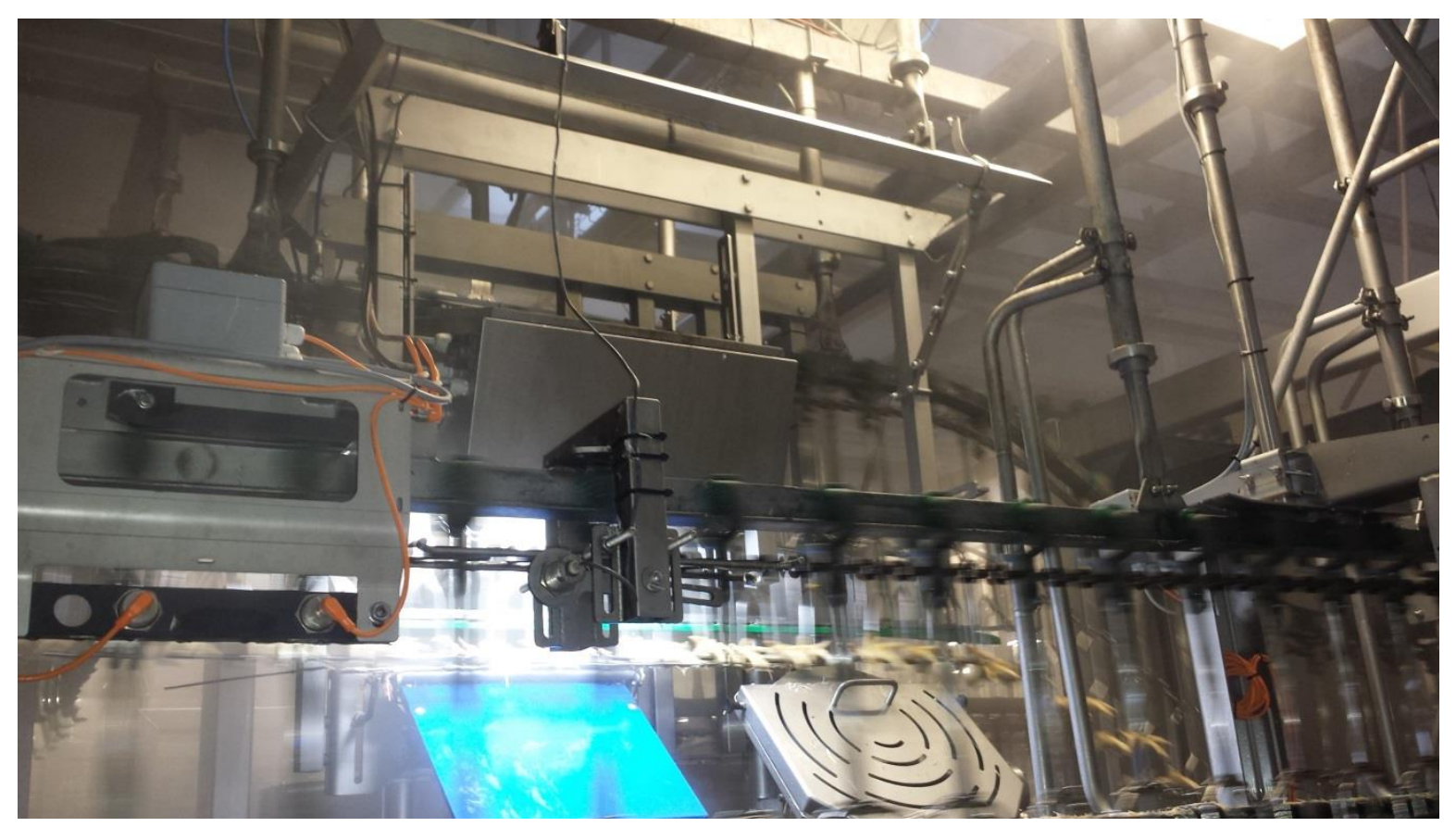

Figuur 2.2 Cameraopstelling in de slachterij.

Figuur 2.3 geeft weer hoe de looppoten door de camera in beeld gebracht worden en een voorbeeld van het uitleesscherm van het systeem. 


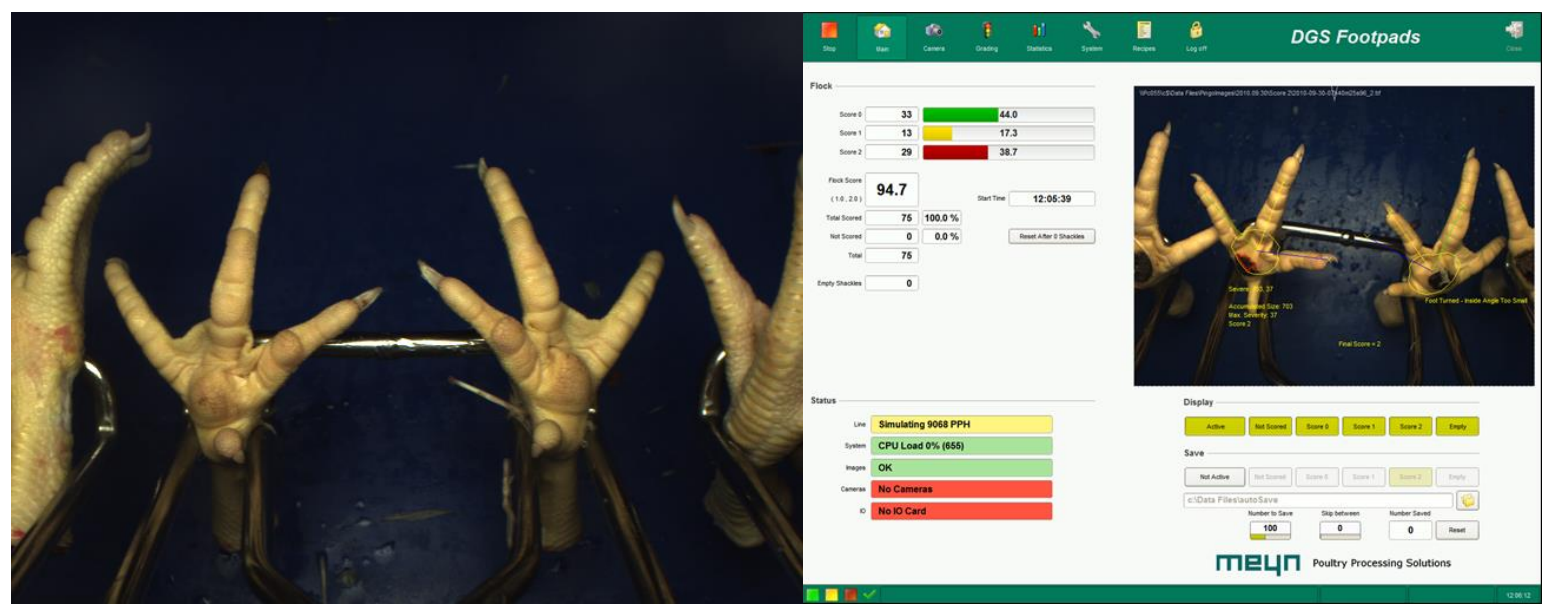

Figuur 2.3 Links: camerabeeld van de looppoten in de slachthaken tijdens de metingen (deze poten kregen de score 0); rechts: schermafbeelding van het systeem.

\subsection{Verzamelen looppoten en beelden}

Op maandag 20 februari 2017 en maandag 15 mei 2017 werd een bezoek gebracht aan de slachterij en zijn metingen uitgevoerd bij alle koppels vleeskuikens die op die dag werden geslacht. Een koppel is daarbij gedefinieerd als alle dieren afkomstig uit dezelfde stal die op hetzelfde moment werden afgeleverd aan de slachterij. Per koppel zijn één tot vier steekproeven genomen. Bij iedere steekproef werden er door de camera ca. 400 potenparen gemeten, terwijl de getrainde Wageningen Livestock Research beoordelaar 100 rechterpootjes van deze 400 potenparen handmatig beoordeelde. Een één op één vergelijk was niet mogelijk vanwege de hoge lijnsnelheid (ca. 12.000 kuikens per uur). De procedure ging als volgt: aan het begin van de slachtdag werden twee horloges exact gelijk gezet met de computertijd. Vervolgens werden aan de slachtlijn vlak na de camera 100 rechterpootjes van de slachtlijn gehaald. Hierbij werd de begin- en eindtijd genoteerd. In de tijd dat er handmatig 100 rechterpootjes van de slachtlijn werden gehaald, beoordeelde de camera de pootjes (zowel linker als rechter) van ongeveer 400 kuikens. De beelden van de camera in de verzamelperiode werden bewaard. Vervolgens werd de voetzoollaesiescore van deze bewaarde beelden bepaald met de (aangepaste) software. De voetzoollaesiescore van deze beelden werd vergeleken met de handmatige score van de verzamelde 100 rechterpootjes. Op de eerste slachtdag (20 februari 2017) werden er twintig steekproeven genomen bij zeven koppels afkomstig van vier bedrijven. Op de tweede slachtdag (15 mei 2017) werden er vijftien steekproeven genomen bij elf koppels afkomstig van zes verschillende bedrijven.

Voor het beoordelen van de beelden door de camera is gebruik gemaakt van de nieuwste software instellingen (Bijlage 1 en 2). De software bevat een voor iedere slachterij specifiek gedeelte om de positie van de poten in het midden van de cameraopstelling te krijgen. Daarnaast bestaat de software uit een gedeelte voor de herkenning van de laesie, dit is voor iedere slachterij gelijk. Als laatste is er een instelling voor herkenning van de klassegrens. Deze verschilt tussen hoogbroei of laagbroei slachterijen. Tijdens beide meetdagen werd er in de loop van de dag overgeschakeld van slachtinstelling 'laagbroei' naar 'hoogbroei'. Dit betekent dus dat op beide meetdagen zowel laag- als hoogbroei koppels zijn beoordeeld. In de analyse van de gegevens wordt daarom ook nagegaan of dit van invloed is geweest op de mate van overeenkomst tussen de camera-score en de referentiescore. Tijdens de validaties varieerde de temperatuur in de broeibak tussen 50.5 en $59^{\circ} \mathrm{C}$ bij hoogbroei en tussen 51.5 en $52.2^{\circ} \mathrm{C}$ bij laagbroei. Deze temperatuurinstellingen (en de verblijfsduur in de zones van de broeibak) zijn slachterijspecifiek.

\subsection{Vergelijking camera met handmatige meting}

Voor de beoordeling van het camerasysteem is van belang hoe de scoring van het camerasysteem zich verhoudt tot de score van de getrainde Wageningen Livestock Research beoordelaar, hierna kort 
WLR-beoordelaar genoemd. De poten zijn beoordeeld aan de hand van de scorekaart die in 2011 door Wageningen Livestock Research is ontwikkeld en in 2014 is verfijnd (scorekaart versie 1.3 - Bijlage 3). De scoringsmethodiek is gebaseerd op de zogenaamde 'Zweedse' scoremethode van voetzoollaesies (Berg, 1998). Deze methode deelt de voetzoollaesies in aan de hand van drie klassen, in het kort omschreven als:

- Klasse 0: geen laesie; geen verkleuring of zeer geringe bruinverkleuring van de voetzool of nagenoeg genezen laesie;

- Klasse 1: milde laesie; oppervlakkige aantasting, bruin of zwart verkleuring;

- Klasse 2: ernstige laesie; aantasting tot in de diepere huidlagen (laesie), gaat samen met onderhuidse ontsteking en/of bloedkorsten of gezwollen voetzool ('bumble foot)'.

Alleen de voetzool werd meegenomen in de beoordeling (De Jong et al., 2011). Ook de camera beoordeelt alleen de zool en neemt verkleuring aan de tenen niet mee.

Data van de camera en handmatige meting van voetzoollaesies worden als volgt vergeleken:

- $\quad$ vergelijking van percentage laesies in de klassen 0,1 en 2;

- $\quad$ vergelijking van de voetzoollaesiesscores (Footpad Score, FPS). De FPS werd als volgt berekend:

FPS $=([$ aantal pootjes klasse $1 \times 0,5]+$ [aantal pootjes klasse $2 \times 2]) \times 100 /$ Ntotaal (De Jong et al., 2011);

- Vergelijking meten van beide voetzolen (en ernstigste score bewaren) met beoordelen van alleen de linker- of rechter poot.

\section{$2.4 \quad$ Dataverwerking}

\subsubsection{Berekening correlaties}

In eerste instantie zijn in het spreadsheet programma Excel de correlaties tussen de eindscores van de camera en die van de WLR-beoordelaar bepaald. De gevonden correlatie tussen de camera en WLR-beoordelaar is vergeleken met de gewenste situatie waarbij er $100 \%$ overeenkomst is tussen camera en WLR-beoordelaar. In hoofdstuk 3 worden de resultaten weergegeven op koppelniveau, in de bijlage worden de resultaten ook weergegeven op steekproefniveau (er zijn soms meerdere steekproeven uit een koppel genomen). Bij de interpretatie van de data moet rekening gehouden worden met de beperkte omvang van de proef.

\subsubsection{Statistische analyse}

Daarnaast zijn de resultaten statisch geanalyseerd met behulp van Genstat (versie 18.1). Hierbij is het volgende model gebruikt:

$$
\begin{aligned}
& \underline{Y}_{i j k l}=\beta_{0, i=1}+\beta_{1} * X_{i j k l}+\Delta \beta_{0, i=2}+\underline{\varepsilon}_{i j}+\underline{\varepsilon}_{i j k}+\underline{\varepsilon}_{i j k l} \\
& \text { Met : } \\
& \underline{Y}_{i j k l}: \quad \text { Camera totaalscore van steekproef / van vleeskuikenkoppel k, afkomstig van } \\
& x: \quad \text { Referentie_totaalscore (behorend bij een Camera_totaalscore) } \\
& \beta_{0, i=1} \text { : } \quad \text { Intercept van de lineaire regressielijn van camera-totaalscore (y) op referentie_totaalscore } \\
& \beta_{1} \text { : } \quad \text { Helling van de lineaire regressie van camera-totaalscore }(\mathrm{y}) \text { en referentie_totaalscore }(\mathrm{x}) \\
& \Delta \beta_{0, i=2} \quad \text { Verschil (ten opzichte van situatie met laagbroei) in Intercept van de lineaire regressielijn van } \\
& \underline{\varepsilon}_{i j} \quad \text { Random afwijking van vleeskuikenbedrijf } \mathrm{j} \sim \mathrm{N}\left(0, \sigma_{i j}^{2}\right) \\
& \underline{\varepsilon}_{i j k} \quad \text { Random afwijking van vleeskuikenkoppel } k \sim \mathrm{N}\left(0, \sigma_{i j k}^{2}\right) \\
& \underline{\underline{\varepsilon}} \cdot i j k l \quad \text { Random afwijking van steekproef } I \sim \mathrm{N}\left(0, \sigma{ }^{2} i j k l\right) \text {; Deze residuele variantie wordt geschat per } \\
& \text { traject. o.b.v de referentie_totaalscore (traject } 1=0-9 \text {; traject } 2=10-66 \text {; traject } 3=67-132 \text {; } \\
& \text { traject 4=133-190; traject 5=191-200). }
\end{aligned}
$$




\subsubsection{Vergelijking meten van beide voetzolen met beoordelen van alleen de linker- of rechter poot}

Vanuit de sector wordt aangegeven dat de camera 'strenger' scoort dan de handmatige beoordelaars. Als reden hiervoor wordt opgegeven dat het camerasysteem beide pootjes van een dier scoort en hiervan de meest ernstige score bewaart, terwijl bij een handmatige scoring alleen het rechterpootje wordt gescoord. De software van het camerasysteem is echter zo ontwikkeld dat voetzoollaesiescore op basis van beide pootjes overeenkomt met die van de referentiescore (gouden standaard), waarbij dus alleen het rechter pootje wordt beoordeeld. Binnen dit onderzoek is ook gekeken naar de verschillen in voetzoollaesiescore tussen de WLR-beoordelaar en het camerasysteem, wanneer de camera beide poten meet en de meest ernstige score bewaart, of alleen de linker of alleen de rechter pootjes meet. 


\section{Resultaten}

\subsection{Performance camerasysteem}

Tabel 3.1 geeft voor iedere steekproef het totaal aantal verzamelde beelden, het aantal gemeten/beoordeelde beelden, het aantal niet gemeten/beoordeelde beelden en het percentage niet beoordeelde beelden. Uit deze tabel blijkt dat gemiddeld over alle steekproeven $1,0 \% \pm 1,1 \%$ van de beelden niet beoordeeld kon worden en dat dus 99 procent van alle beelden (lees: kuikens) gebruikt kon worden.

Tabel 3.1 Totaal aantal beelden verzameld, het aantal beoordeelde beelden, het aantal niet beoordeelde beelden en het percentage niet door de camera beoordeelde beelden voor iedere steekproef per koppel.

\begin{tabular}{|c|c|c|c|c|c|}
\hline \multirow[t]{2}{*}{ Steekproef } & \multirow[t]{2}{*}{ Koppel } & \multirow{2}{*}{$\begin{array}{c}\text { Totaal } \\
n\end{array}$} & \multirow{2}{*}{$\begin{array}{c}\text { Gemeten } \\
n\end{array}$} & \multicolumn{2}{|c|}{ Niet gemeten } \\
\hline & & & & $\mathrm{n}$ & $\%$ \\
\hline 1 & 1 & 393 & 392 & 1 & 0,3 \\
\hline 2 & 2 & 373 & 371 & 2 & 0,5 \\
\hline 3 & 2 & 393 & 392 & 1 & 0,3 \\
\hline 4 & 2 & 358 & 356 & 2 & 0,6 \\
\hline 5 & 3 & 392 & 387 & 5 & 1,3 \\
\hline 6 & 3 & 372 & 369 & 3 & 0,8 \\
\hline 7 & 3 & 367 & 365 & 2 & 0,5 \\
\hline 8 & 4 & 412 & 412 & 0 & - \\
\hline 9 & 4 & 374 & 373 & 1 & 0,3 \\
\hline 10 & 4 & 414 & 413 & 1 & 0,2 \\
\hline 11 & 4 & 371 & 368 & 3 & 0,8 \\
\hline 12 & 5 & 372 & 371 & 1 & 0,3 \\
\hline 13 & 5 & 345 & 343 & 2 & 0,6 \\
\hline 14 & 5 & 441 & 440 & 1 & 0,2 \\
\hline 15 & 6 & 438 & 437 & 1 & 0,2 \\
\hline 16 & 6 & 442 & 439 & 3 & 0,7 \\
\hline 17 & 6 & 423 & 423 & 0 & - \\
\hline 18 & 6 & 344 & 343 & 1 & 0,3 \\
\hline 19 & 7 & 412 & 408 & 4 & 1,0 \\
\hline 20 & 7 & 376 & 375 & 1 & 0,3 \\
\hline 21 & 8 & 389 & 375 & 14 & 3,6 \\
\hline 22 & 9 & 331 & 328 & 3 & 0,9 \\
\hline 23 & 9 & 447 & 440 & 7 & 1,6 \\
\hline 24 & 10 & 400 & 394 & 6 & 1,5 \\
\hline 25 & 10 & 380 & 376 & 4 & 1,1 \\
\hline 26 & 11 & 348 & 348 & 0 & - \\
\hline 27 & 12 & 398 & 389 & 9 & 2,3 \\
\hline 28 & 12 & 330 & 325 & 5 & 1,5 \\
\hline 29 & 13 & 337 & 335 & 2 & 0,6 \\
\hline 30 & 13 & 297 & 296 & 1 & 0,3 \\
\hline 31 & 14 & 497 & 485 & 12 & 2,4 \\
\hline 32 & 15 & 361 & 351 & 10 & 2,8 \\
\hline 33 & 16 & 404 & 396 & 8 & 2,0 \\
\hline 34 & 17 & 409 & 399 & 10 & 2,4 \\
\hline 35 & 18 & 346 & 330 & 16 & 4,6 \\
\hline
\end{tabular}




\subsection{Vergelijking per scoringsklasse}

In de figuren 3.1 tot en met 3.3 worden de overeenkomsten tussen het camerasysteem en de getrainde WLR-beoordelaar per score klasse op koppelniveau weergegeven. Hieruit blijkt dat er goede overeenkomsten zijn tussen het camerasysteem en de WLR-beoordelaar voor de voetzoolscore klassen $0\left(R^{2}=0,99\right)$ en $2\left(R^{2}=0,95\right)$. Voor score klasse 1 laat het camerasysteem een overschatting zien $\left(R^{2}=0,40\right)$. Voor score klasse 1 heeft het systeem te maken met twee grenzen (score 0 vs 1 en 1 vs 2). In Bijlage 4 worden de scores per klasse van zowel de WLR-beoordelaar als van het camerasysteem per steekproef vermeld en in Bijlage 5 wordt, eveneens op steekproefniveau, per score klasse de overeenkomsten tussen de WLR-beoordelaar en het camerasysteem grafisch weergegeven.

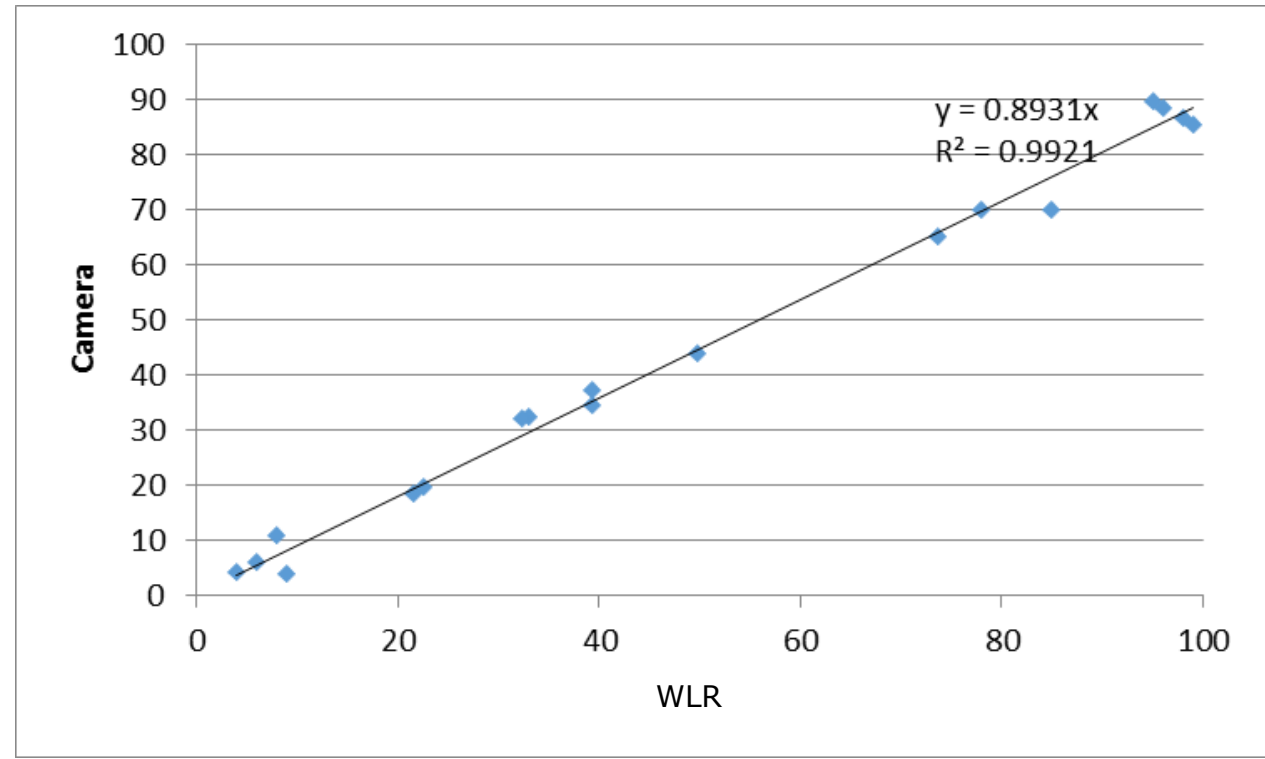

Figuur 3.1 Correlatie camera en getrainde WLR-beoordelaar in klasse 0 (geen laesie). De assen geven het percentage pootjes weer gescoord door WLR of de camera in klasse 0 (per koppel). De zwarte lijn geeft de situatie bij 100\% overeenkomst tussen camera en WLR-beoordelaar weer.

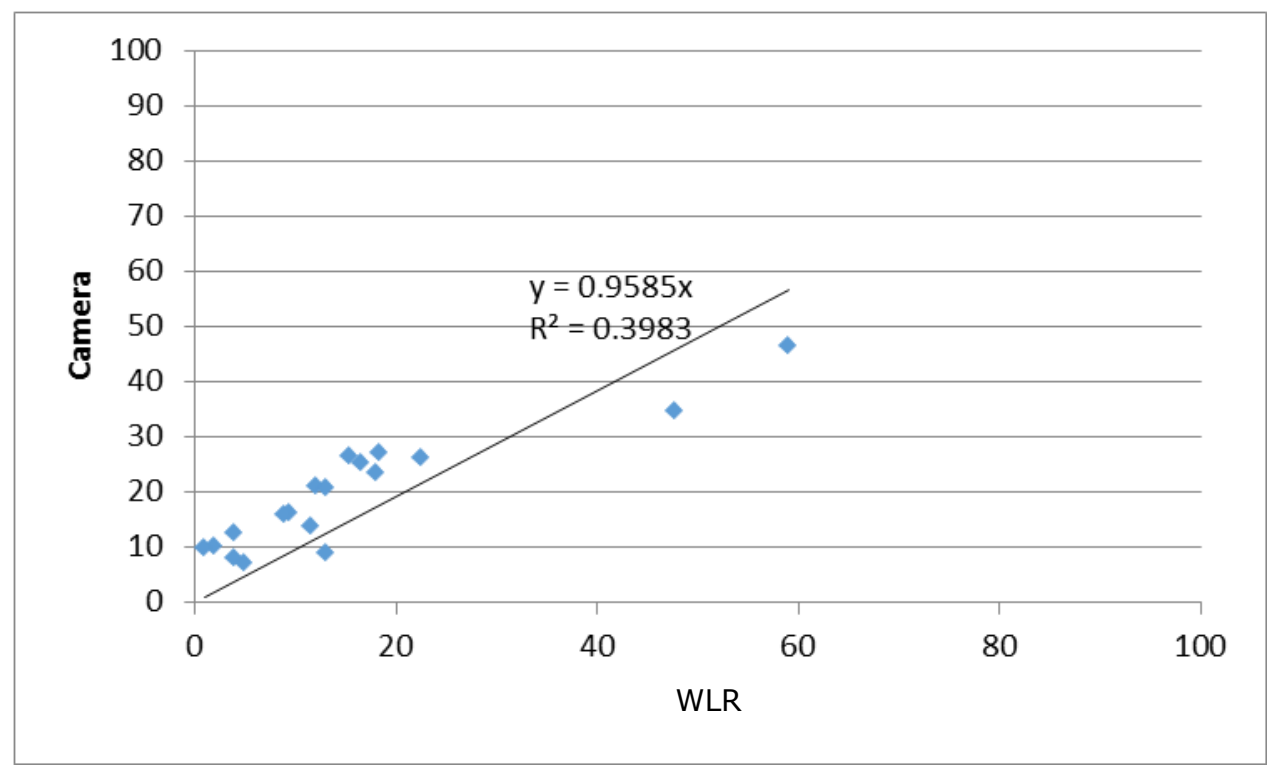

Figuur 3.2 Correlatie camera en getrainde WLR-beoordelaar in klasse 1 (milde laesie). De assen geven het percentage pootjes weer gescoord door WLR of de camera in klasse 1 (per koppel). De zwarte lijn geeft de situatie bij 100\% overeenkomst tussen camera en WLR-beoordelaar weer. 


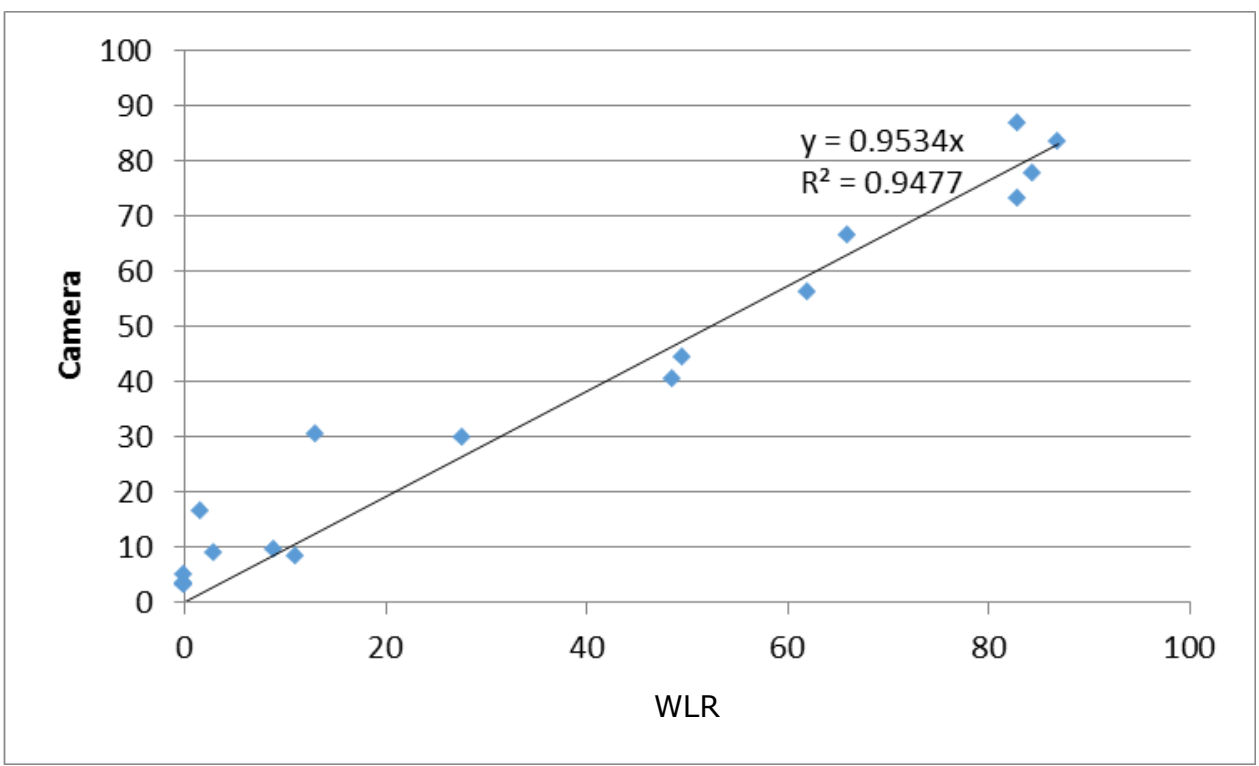

Figuur 3.3 Correlatie camera en getrainde WLR-beoordelaar in klasse 2 (ernstige laesie). De assen geven het percentage pootjes weer gescoord door WLR of de camera in klasse 2 (per koppel). De zwarte lijn geeft de situatie bij 100\% overeenkomst tussen camera en WLR-beoordelaar weer.

\subsection{Vergelijking voetzoollaesiescore}

In Figuur 3.4 zijn de voetzoollaesiescores van alle koppels (18 in totaal) van het camerasysteem uitgezet ten opzichte die van de WLR-beoordelaar. We zien dat de voetzoollaesiescores van het camerasysteem de scores van de getrainde WLR-beoordelaar goed volgen. Opvallend is wel dat bij koppels met een lage voetzoollaesiescore (FPS $<60$ ) het camerasysteem structureel (iets) hoger scoort dan de WLR-beoordelaar. Ook is het opvallend dat het camerasysteem bij koppelnummers 3 en 4 te hoog scoort. Beide koppels zijn afkomstig van hetzelfde bedrijf. In bijlage 7 worden de voetzoollaesiescores van het camerasysteem en de WLR-beoordelaar van alle genomen steekproeven (35 in totaal) alsmede de relatie tussen deze scores grafisch weergegeven.

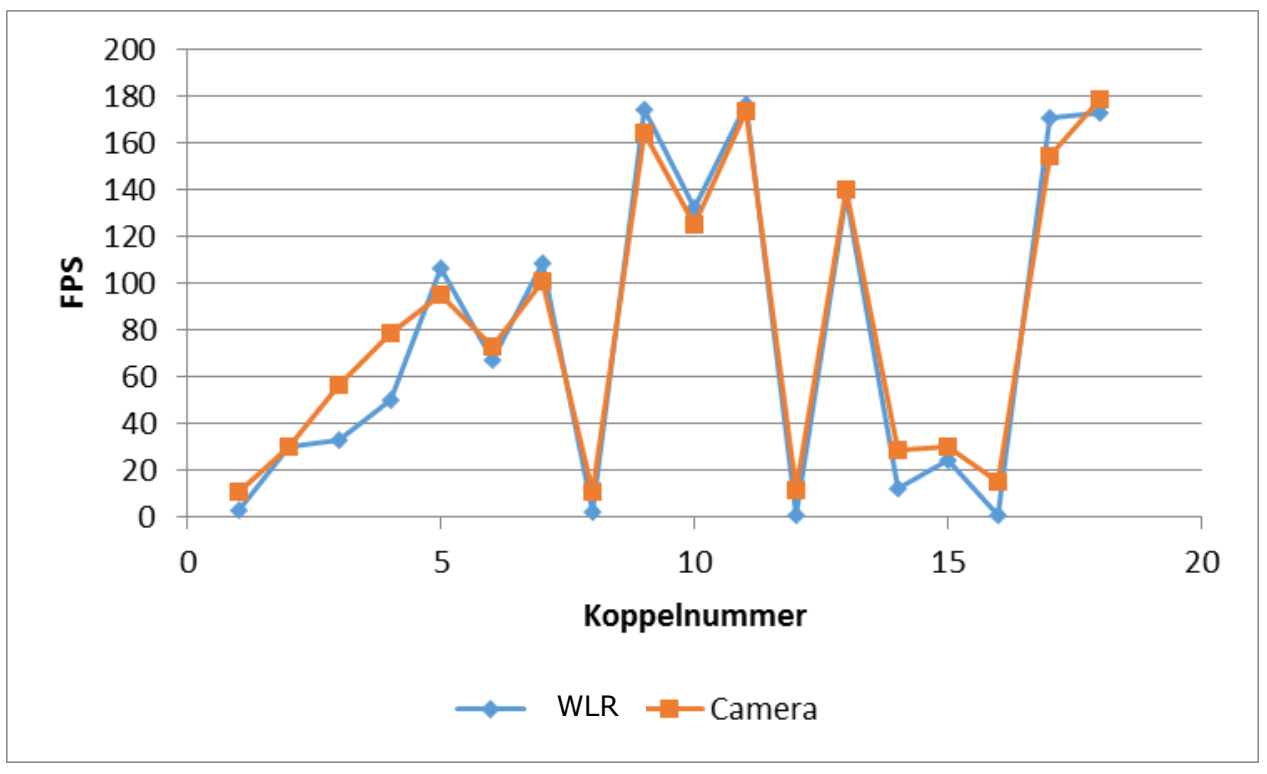

Figuur 3.4 Grafische weergave van de verschillen in voetzoollaesiescore (FPS) per koppel tussen het camerasysteem en de getrainde WLR-beoordelaar.

In Figuur 3.5 is de relatie weergegeven tussen het camerasysteem en de WLR-beoordelaar voor wat betreft voetzoollaesiescores. Hieruit blijkt dat het camerasysteem bij koppels met een lage incidentie aan ernstige voetzoollaesies (dus koppels met een lage voetzoollaesiescore) de voetzoollaesiescore overschat en bij koppels met een hoge incidentie aan ernstige voetzoollaesies (koppels met een hoge 
voetzoollaesiescore) de voetzoollaesiescore enigszins onderschat. Deze onderschatting is relatief kleiner dan de overschatting van de lage voetzoolaesiescores.

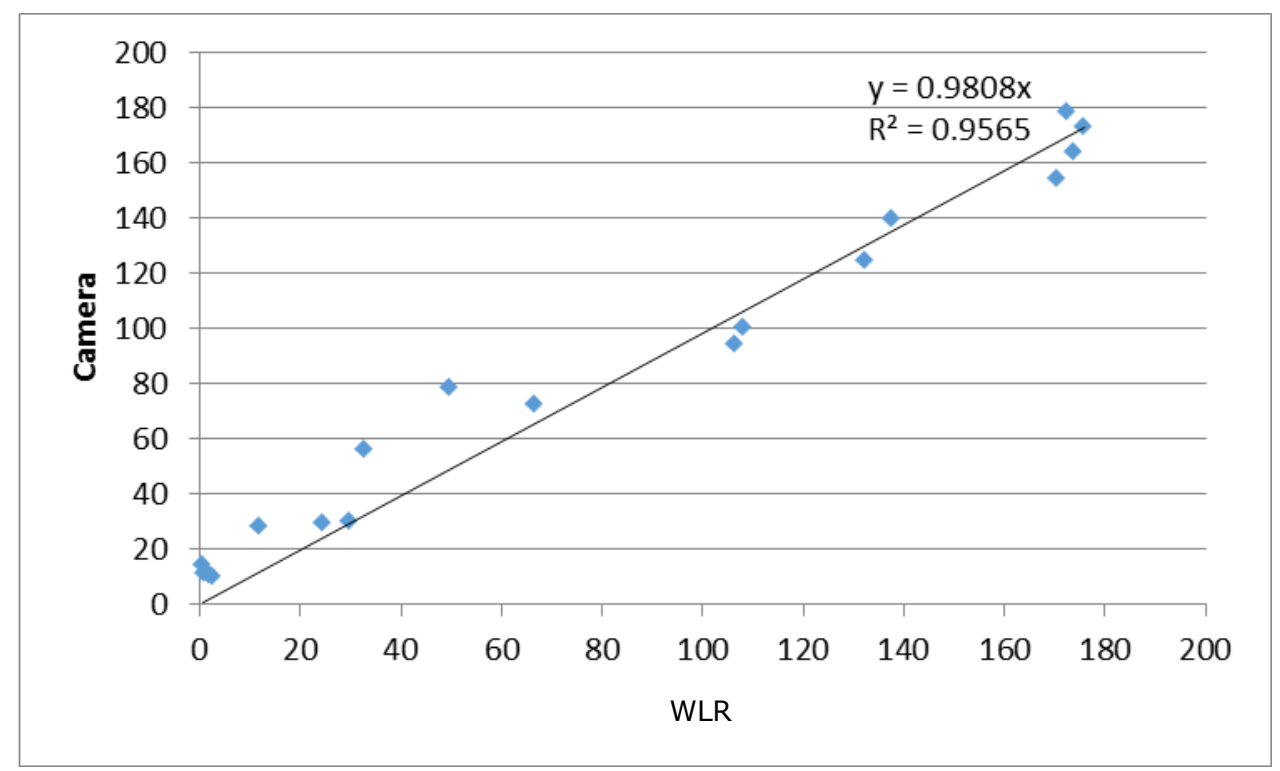

Figuur 3.5 Relatie tussen de voetzoollaesiescores (FPS) per koppel gegeven door de camera en de getrainde WLR-beoordelaar. De zwarte lijn geeft de situatie bij $100 \%$ overeenkomst tussen camera en $W L R$-beoordelaar weer.

\subsection{Vergelijking laag-en hoogbroei}

Aangezien uit een eerdere validatie was gebleken dat de broeiwijze een effect had op de voetzoollaesiescore hanteert Meyn verschillende recepten voor laag- en hoogbroei. Binnen deze validatie zijn zowel 'laagbroei' als 'hoogbroei' koppels gescoord. Het bleek dat de broeiwijze geen effect had op de prestaties van het camerasysteem. Zowel bij hoog- als laagbroei is de overeenkomst in voetzoollaesiescore tussen het camerasysteem en de getrainde WLR-beoordelaar hoog ( $R^{2}$ bij laagen hoogbroei waren respectievelijk 0,95 en 0,97).

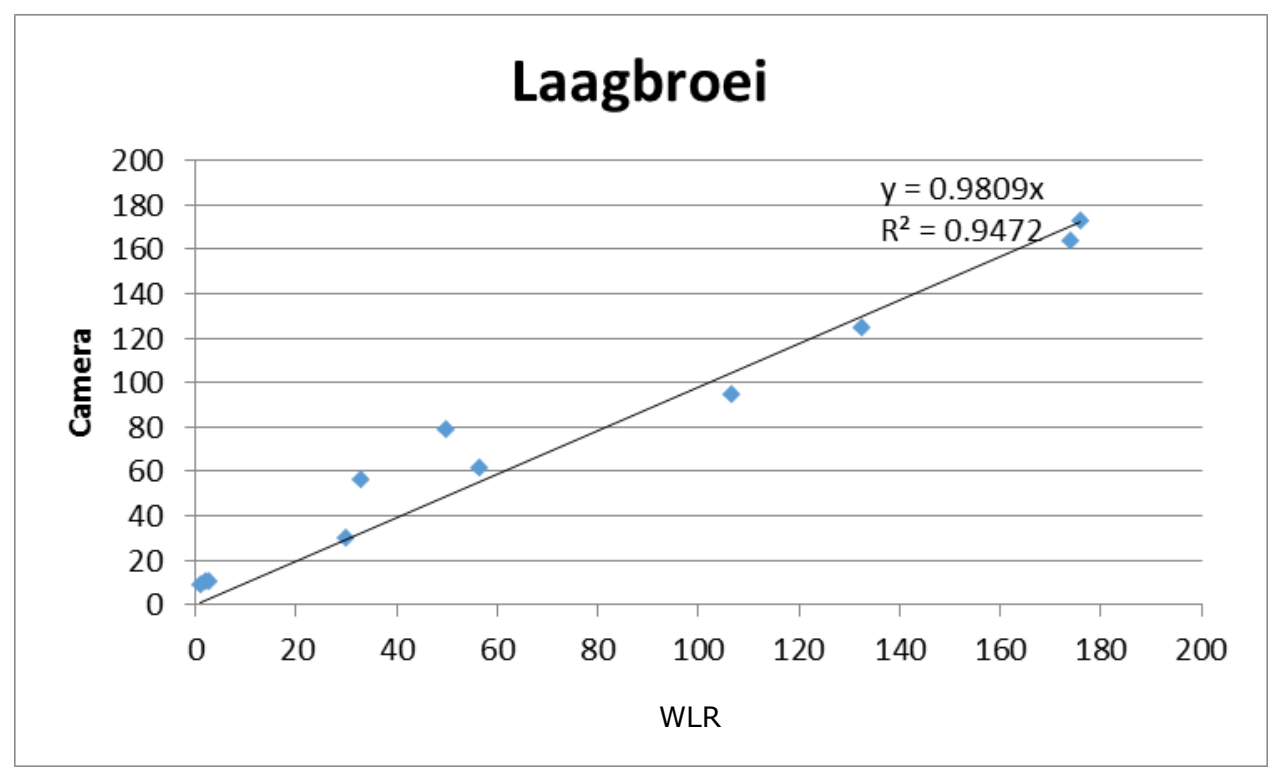

Figuur 3.6 Relatie tussen de voetzoollaesiescores (FPS) bij alle laagbroei koppels gegeven door de camera en de getrainde WLR-beoordelaar. De zwarte lijn geeft de situatie bij $100 \%$ overeenkomst tussen camera en WLR-beoordelaar weer. 


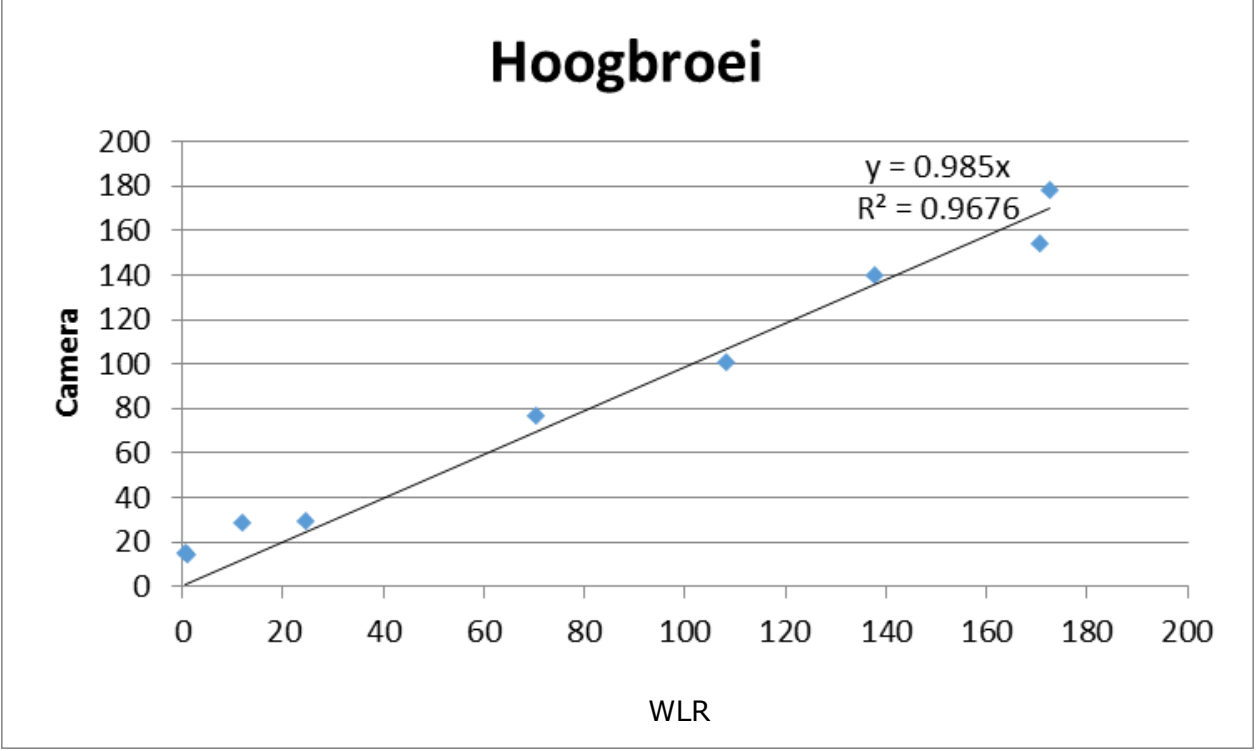

Figuur 3.7 Relatie tussen de voetzoollaesiescores (FPS) bij alle hoogbroei koppels gegeven door de camera en de getrainde WLR-beoordelaar. De zwarte lijn geeft de situatie bij $100 \%$ overeenkomst tussen camera en WLR-beoordelaar weer.

\subsection{Statistische analyse}

De resultaten van de statistische analyse staan weergegeven in Bijlage 11. Uit deze analyse blijkt, evenals uit de vorige figuren, dat de camera bij de lage scores een overschatting geeft en bij de hoge scores een lichte onderschatting geeft ten opzichte van de handmatige scoring. De statistische analyse laat zien dat dit effect het grootst is bij hoogbroei.

Tevens laat deze analyse duidelijk zien dat er een bedrijfseffect is, d.w.z. dat voor een specifiek bedrijf de afwijking in de score van de camera groter kan zijn. Dit betekent dat de fout van de camera groter is bij pootjes van bepaalde vleeskuikenbedrijven. Het gevonden bedrijfseffect bleek extreem groot op één vleeskuikenbedrijf, waar de koppelscore van de camera meer dan 20 punten hoger lag dan de score van de getrainde WLR-beoordelaar. De voetzoollaesiescores van dit vleeskuikenbedrijf lagen allemaal in een beperkt traject (rond de referentiescore van 50 punten). Het is dus statistisch gezien niet helemaal uit te sluiten dat de afwijking laesie type gebonden is (- grote doch oppervlakkige laesie), i.p.v. vleeskuikenbedrijf-gebonden.

Hierbij moet ook opgemerkt worden dat dit effect relatief groot wordt ingeschat omdat tijdens het meten relatief veel steekproeven genomen zijn van de twee koppels van dit bedrijf (in verhouding tot de andere steekproeven).

\subsection{Vergelijking meten van beide voetzolen met beoordelen van alleen de linker- of rechter poot}

In Figuur 3.8 wordt de voetzoollaesiescore van de WLR-beoordelaar vergeleken met die van het camerasysteem, op basis van 1) beide pootjes (waarbij de meest ernstige score is bewaard), 2) alleen linkerpootjes en 3) alleen rechterpootjes. Hieruit blijkt dat wanneer de camera de meest ernstige score van beide poten bewaart, de eindscore hoger is dan wanneer alleen de linker- of rechterpoot wordt gescoord. De camerascore van beide poten, waarbij de meest ernstige score wordt bewaard, komt het beste overeen met de score van de getrainde WLR-beoordelaar. Op zich niet verwonderlijk aangezien de software hierop gebaseerd is. De eindscores van alleen linker- of rechterpootjes liggen duidelijk lager dan die van de WLR-beoordelaar. De voetzoollaesiescore op basis van alleen de linkerpootjes was hoger dan die op basis van alleen de rechterpootjes, hetgeen overeenkomt met eerder onderzoek van De Jong et al. (2011). Gemiddeld over alle koppels bedroeg de 
voetzoollaesiescore van de camera op basis van beide pootjes (hoogste score bewaard), alleen linkeren rechterpootjes, respectievelijk 82, 70 en 64 (voetzoollaesiescore WLR-beoordelaar: 78).

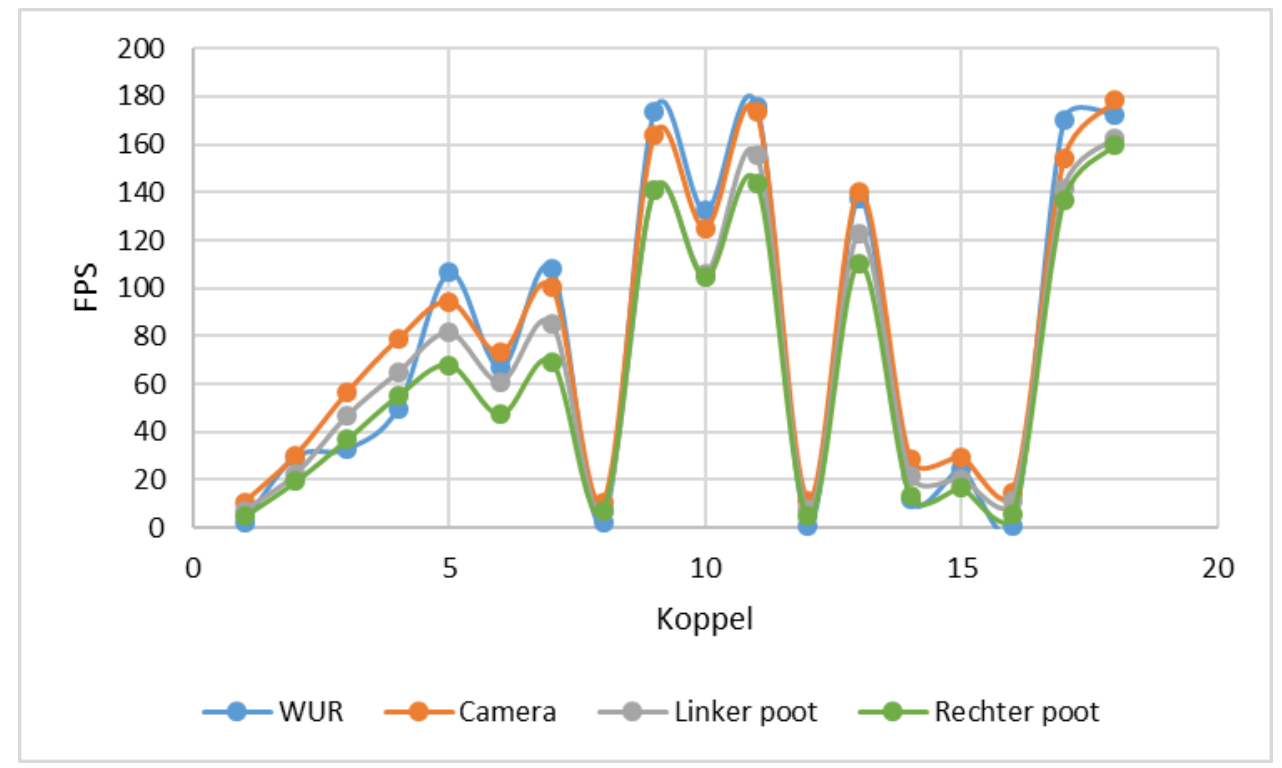

Figuur 3.8 Vergelijking voetzoollaesiescore WLR-beoordelaar met het camerasysteem waarbij de camera op drie manieren heeft gescoord: beide zolen (waarbij de meest ernstige score is bewaard), alleen de linkerpoot of alleen de rechterpoot. 


\section{Discussie}

Het aantal poten dat door de camera beoordeeld kon worden ligt met $99 \%$ ruim boven het minimum van $70 \%$ zoals in eerder onderzoek werd gedefinieerd (De Jong et al., 2011). Dit betekent dat met het Meyn Footpad Inspection System de voetzolen van vrijwel alle kuikens van het koppel gemeten/beoordeeld kunnen worden. Dit wordt als een grote pré gezien van het systeem. Het is immers bekend dat variatie kan zijn in de score binnen een koppel, bijvoorbeeld doordat natte plekken (als gevolg van lekkage, condens, tocht, niet uniforme lichtverdeling, e.d.) in de stal kunnen zorgen voor toename van voetzoollaesies in een deel van het koppel (De Jong, et al., 2012). Omdat de camera vrijwel alle kuikens kan beoordelen zal deze een betrouwbaarder beeld van de ernst en voorkomen van voetzoollaesies in een koppel geven in vergelijking met een handmatige meting o.b.v. een steekproef van slechts twee keer 50 pootjes verzameld rond $30 \%$ en $60 \%$ van de verwerking van een koppel (zoals bepaald in de Regeling houders van dieren). Ter illustratie, een steekproef van 100 pootjes op een klein (6000) of groot koppel (30.000) is respectievelijk $1.7 \%$ en $0,33 \%$. Ook meet de camera beide poten (waarbij het eindoordeel gebaseerd wordt op het pootje met de meest ernstige score), in tegenstelling tot alleen de rechterpoot bij een handmatige meting. Daarnaast is er de kans dat een waarnemer niet consequent scoort, maar (onbewust) de methodiek aanpast afhankelijk van de ernst van voetzoollaesies van het koppel. Een camera zal altijd op dezelfde wijze meten. Het camerasysteem is wel prijzig, maar het bespaart arbeid en beelden kunnen worden bewaard zodat eventueel achteraf de score gecontroleerd kan worden (De Jong et al., 2011).

Op beide meetdagen werden in totaal 18 koppels bemeten. Gemiddeld genomen lag de voetzoollaesiescore over alle achttien aangeleverde koppels van het camerasysteem iets hoger dan die van de getrainde WLR-beoordelaar: 82 t.o.v. 78. Tien koppels hadden een voetzoollaesiescore lager dan 80, twee koppels een score tussen 80 en 120, en zes koppels een score hoger dan 120. In het traject tussen 80 en 120 punten zijn dus relatief weinig koppels bemeten. Dit was echter inherent aan de gekozen opzet, dat wil zeggen de keuze aan koppels binnen een bepaald gebied met voetzoollaesiescores is immers afhankelijk van hetgeen wordt aangeleverd op de meetdagen. Bovendien was er gekozen voor een zeer beperkte validatie. In de ideale situatie wordt de validatie uitgevoerd op meer dagen dan in deze studie is gedaan.

De overeenkomst in voetzoollaesiescores tussen de camera en de getrainde beoordelaar van WLR is over het algemeen goed te noemen. De camera scoort in het lage gebied (FPS tussen 0 - 60 punten) iets hoger/zwaarder dan de WLR-beoordelaar, terwijl het camerasysteem in het hoge gebied (FPS > 120) iets lager/milder scoort. Het verschil tussen camera en getrainde beoordelaar is groter bij hoogbroei dan bij laagbroei. In het tussenliggende traject komt de score van de camera goed overeen met die van de getrainde WLR-beoordelaar. Een van de mogelijke oorzaken dat het camera in het lage gebied hoger scoort is de positie van de poot in de haak. Hierdoor kan het zijn dat de poot gedraaid wordt aangeboden, en/of een loopteen van een ander dier in beeld zit waardoor de camera schaduw meet, of een verkeerd gebied meet (dus niet de voetzool), waardoor een klasse 0 laesie (geen aandoening) wordt gezien door de camera als een klasse 1 of klasse 2 laesie. In Bijlage 8 worden een aantal voorbeelden van foutief gemeten pootjes door het camerasysteem weergegeven. In dit onderzoek kwam het niet voor dat achtergebleven vuil op/in de laesie zorgde voor een foutieve beoordeling, maar het is niet uit te sluiten dat dit in de praktijk ook kan voorkomen. En andere mogelijke verklaring voor het feit dat de camera wat zwaarder scoort in het lage gebied (FPS 0-60 punten) is dat de kans op het afnemen van het rechterpootje uit de lijn met een laesie bij een schoon koppel relatief klein is terwijl de camera alle 400 pootjes beoordeelt. Elk gemist pootje met laesie wordt dan niet meegenomen in de handmeting, terwijl deze wel wordt meegenomen bij de camerameting.

De statistische analyse heeft laten zien dat er sprake kan zijn van een bedrijfseffect, mogelijk samenhangend met het gebied waarin de score van het bedrijf valt. Het valt daarom niet uit te sluiten dat het systeem met bepaalde typen pootjes een grotere afwijking heeft, echter, om hier uitspraken over te doen is uitgebreider onderzoek aan een groter aantal koppels noodzakelijk. 
De validatie van het camerasysteem was een heel beperkte validatie vanwege financiële beperkingen. Dat betekent dat er een aantal aandachtspunten zijn en aanbevelingen voor een meer uitgebreide validatie:

- Er is in deze uitvoering gewerkt met het trekken van extra steekproeven uit dezelfde koppel als er grote afwijkingen waren tussen koppelscore en de score van de getrainde WLR-beoordelaar. Steekproef-technisch is dit echter niet correct. Indien nagegaan moet worden of afwijkingen binnen een koppel gecorreleerd zijn, dienen van alle koppels evenveel steekproeven genomen te worden. Vanwege het beperkte aantal steekproeven hebben wij er echter voor gekozen alle steekproeven mee te nemen in de analyse.

- Idealiter zou de beoordelaar, na zijn beoordeling, de score van het camerasysteem niet mogen weten, maar omdat men de performance van de camera wilde weten is dit wel gedaan en indien de score van de camera afweek van die van de WLR-beoordelaar werd een nieuwe steekproef binnen dezelfde koppel genomen. Dit werd gedaan om meer inzicht te krijgen in de afwijking van het camerasysteem ten opzichte van die van de WLR-beoordelaar.

- De steekproeven zijn op twee dagen uitgevoerd. De camerasoftware voor vertaling van de beelden naar scores is na de eerste steekproefdag (met informatie per steekproef van de referentiescores van de eerste dag) nog aangepast. Strikt genomen zijn de data van de eerste dag daarmee ongeschikt als validatiedata. Vanwege de beperking van het aantal koppels en steekproeven wanneer alleen gebruik gemaakt zou worden van de tweede meetdag worden deze daarom wel in dit rapport vermeld, waarbij alle beelden van beide meetdagen zijn beoordeeld met de nieuwe versie van de software.

- Op beide meetdagen werd in de loop van de dag overgegaan van laagbroei naar hoogbroei. Dit betekent dat de broeiwijze verstrengeld is met de mate van vermoeidheid van de WLRbeoordelaar. Immers deze is aan het begin van de dag, dus bij laagbroei, 'fitter' dan aan het eind van de dag bij hoogbroei. Om dit te ondervangen wordt aanbevolen laag- en hoogbroei op verschillende dagen te meten, aangezien het praktisch niet mogelijk is om tussen koppels over te schakelen op een andere broeiwijze.

Op basis van deze zeer beperkte validatie die hier is uitgevoerd kan niet geconcludeerd worden dat de voetzoollaesiescore van het Meyn Footpad Inspection System sterk afwijkt van die van een getrainde beoordelaar. Gezien de grote mate van overeenkomst van de voetzoollaesiescores van het camerasysteem en de getrainde WLR-beoordelaar, en het feit dat het camerasysteem in staat is vrijwel alle kuikens van een koppel te beoordelen zal de camera mogelijk zelfs een meer betrouwbaar beeld geven van de ernst en voorkomen van voetzoollaesies in een koppel dan een handmatige meting o.b.v. een steekproef van slechts 100 pootjes, ondanks het feit dat er mogelijk een bedrijfseffect is/effect van type laesie dat een grotere afwijking van de camerascore kan veroorzaken.

De software van de camera is ingesteld op de beste overeenkomst tussen de score van het meest ernstige pootje van een potenpaar en de score van de WLR-beoordelaar. Wanneer alleen de score van de linker- of rechterpoot wordt bewaard dan is de totaalscore lager, maar deze komt dan minder goed overeen met de score van de WLR-beoordelaar (wat logischerwijs een gevolg is van het feit dat de camera geijkt is op de meest ernstige score van een potenpaar). Dat de camera de meest ernstige score van een potenpaar bewaart kan daarom geen verklaring zijn voor de door de praktijk aangegeven mogelijke afwijking van de camera ten opzichte van een handmatige beoordeling.

In 2015 heeft Wageningen Livestock Research eveneens een validatie van het camerasysteem uitgevoerd bij een andere vleeskuikenslachterij (data niet gepubliceerd). De opgeslagen beelden van deze validatie zijn met de nieuwe software opnieuw beoordeeld. Het blijkt dat de voetzoollaesiescores van het camerasysteem goed overeenkomen met die van de WLR-beoordelaar (Figuur 4.1 en 4.2; $\left.\mathrm{R}^{2}=0,92\right)$. Dit komt dus goed overeen met de resultaten van de validatie die in dit rapport wordt beschreven. In 2015 werden er in totaal 8 koppels bemeten. Gemiddeld genomen lag de voetzoollaesiescore over alle acht aangeleverde koppels van het camerasysteem iets hoger dan die van de getrainde WLR-beoordelaar: 63 t.o.v. 58. Zes koppels hadden een voetzoollaesiescore lager dan 80, twee koppels een score tussen 80 en 120, terwijl er geen koppels waren met een score van boven de 120 . 


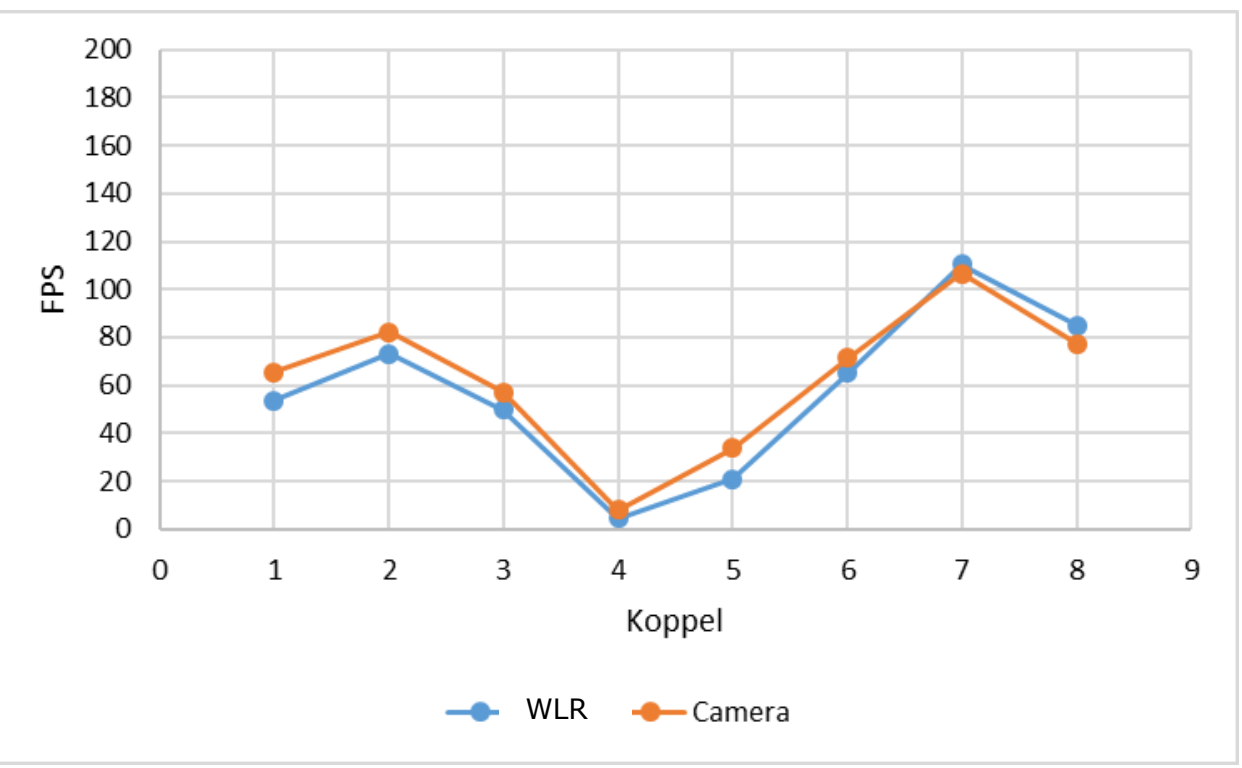

Figuur 4.1 Grafische weergave van de verschillen in voetzoollaesiescore (FPS) per koppel, op basis van de beelden van de validatie bij een vleeskuikenslachterij in 2015, tussen het camerasysteem en de getrainde WLR-beoordelaar.

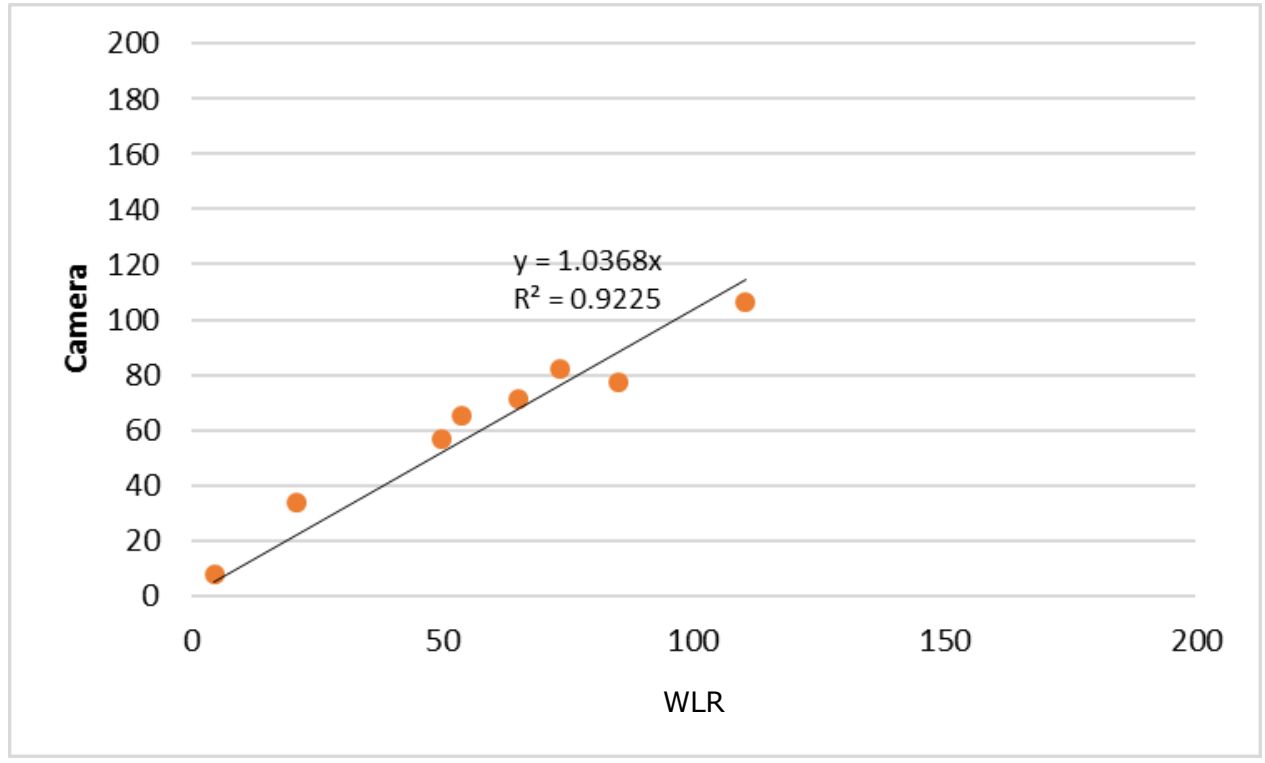

Figuur 4.2 Relatie tussen de voetzoollaesiescores (FPS) per koppel gegeven door de camera en de getrainde WLR-beoordelaar op basis van de beelden van de uitgevoerde validatie bij Clazing in 2015. De zwarte lijn geeft de situatie bij 100\% overeenkomst tussen camera en WLR-beoordelaar weer. 


\section{$5 \quad$ Conclusies}

Op basis van een beperkte vergelijking van beoordeling van voetzoollaesies door het Meyn Footpad Inspection System en handmatig door een getrainde WLR-beoordelaar lijkt het camerasysteem de scores van de getrainde WLR-beoordelaar goed te volgen. Gezien de grote mate van overeenkomst tussen de gemeten voetzoollaesiescores door het camerasysteem en de getrainde WLR-beoordelaar, en het feit dat het camerasysteem in staat is vrijwel alle kuikens van een koppel te beoordelen, zal de camera mogelijk een betrouwbaarder beeld geven van de ernst en het voorkomen van voetzoollaesies in een koppel dan een handmatige meting o.b.v. een steekproef van slechts 100 pootjes. Wel is er mogelijk een bedrijfseffect is en /of een effect van type/soort laesie waardoor de camerascore kan afwijken. Ook zal een camerasysteem uniformer meten op alle slachterijen, terwijl er zeer waarschijnlijk variatie is in de kwaliteit van de handmatige metingen op verschillende vleeskuikenslachterijen, maar ook binnen slachterijen (tussen verschillende personen).

De camera beoordeelde de laesies gemiddeld iets zwaarder (strenger) dan de WLR-beoordelaar. Hierdoor was de voetzoollaesiescore bij het camerasysteem hoger dan die bij de WLR-beoordelaar (FPS 82 vs. 78). Het camerasysteem gaf bij koppels met weinig voetzoollaesies (FPS $<60)$ een kleine overschatting en bij koppels met ernstige voetzoollaesies (FPS $>120$ ) een kleine onderschatting van de voetzoollaesiescore. In het traject 60 - 120 punten scoort de camera goed. De afwijking van de camera was iets groter bij hoogbroei dan bij laagbroei.

De software van de camera is ingesteld op de beste overeenkomst tussen de score van het meest ernstige pootje van een potenpaar en de score van de WLR-beoordelaar. Dat de camera de meest ernstige score van een potenpaar bewaart, en niet standaard alleen het linker- of alleen het rechterpootje scoort, kan daarom geen verklaring zijn voor de door de praktijk aangegeven mogelijke afwijking van de camera ten opzichte van een handmatige beoordeling. Deze beperkte vergelijking/validatie toont dit ook aan. 


\section{Literatuur}

Berg, C. (1998). Foot-pad dermatitis in broilers and turkeys. Doctoral diss. Dept. of Animal Environment and Health, SLU. Acta Universitatis Agriculturae Sueciae, Sweden.

Jong, I.C. de; Reimert, H.G.M., Vanderhasselt, R., Gerritzen, M.A., Gunnink, H., Harn, J. van; Hindle, V.A., Lourens, A. (2011). Ontwikkeling van methoden voor het monitoren van voetzoollaesies bij vleeskuikens. Wageningen UR Livestock Research Rapport 463

Jong, I.C. de, Harn, J. van, Gunnink, H., Lourens, A., Riel, J.W. van (2012). Measuring foot-pad lesions in commercial broiler houses. Some aspects of methodology. Animal Welfare 21 (3), p. $325-330$.

Jong, I.C. de, 2013. Evaluatie Meyn Footpad Inspection System. Wageningen UR Livestock Research Rapport 713. 


\section{Bijlage 1 Software recept bij laagbroei}

\begin{tabular}{|c|c|c|c|}
\hline \multicolumn{4}{|l|}{ Camera } \\
\hline \multicolumn{4}{|l|}{ Haakpositie } \\
\hline Haakmidden & $\mathbf{x}$ & Voetenafstand & 300 \\
\hline \multicolumn{4}{|l|}{ Voetzoolpositie } \\
\hline Voetbreedtebereik & 70 & Onderkant negeren & 400 \\
\hline Voetdrempel & 30 & Vertikale Afwijking & 110 \\
\hline Teenlengte & 85 & Teenhoek & 33 \\
\hline Verklein Voetgebied & 15 & & \\
\hline \multicolumn{4}{|l|}{ Laesies } \\
\hline Gevoeligheid Rood & 77 & Gevoeligheid Groen & 60 \\
\hline Drempel & 24 & & \\
\hline Negeer heel klein & 79 & Ernstig bij Breedte & 20 \\
\hline Negeer lichtrood & 10 & & \\
\hline \multicolumn{2}{|c|}{ Negeer schaduw bovenaan } & \multicolumn{2}{|l|}{12} \\
\hline & & & \\
\hline \multicolumn{4}{|l|}{ Klassificatie } \\
\hline Score-drempels & Ernst & & Grootte \\
\hline Van 0 naar 1 & 13 & & 280 \\
\hline Van 1 naar 2 & 20 & & 1100 \\
\hline \multicolumn{4}{|l|}{ Bloemigheid } \\
\hline Van 2 naar 1 & 11 & & 250 \\
\hline \multicolumn{4}{|l|}{ Aspectratio } \\
\hline Van 1 naar 2 & AAN & & \\
\hline \multicolumn{4}{|l|}{ Extra Beslissing } \\
\hline Als & 13 & $<$ Ernst $<$ & 24 \\
\hline en $->$ dan score $=1$ & 350 & $<$ Grootte $<$ & 1300 \\
\hline \multicolumn{4}{|c|}{ Weegfactoren voor eindscore } \\
\hline Voor Score 1 & 0.5 & Voor Score 1 & 2.0 \\
\hline
\end{tabular}




\section{Bijlage 2 Software recept bij hoogbroei}

\begin{tabular}{|c|c|c|c|}
\hline \multicolumn{4}{|l|}{ Camera } \\
\hline \multicolumn{4}{|l|}{ Haakpositie } \\
\hline Haakmidden & $\mathbf{x}$ & Voetenafstand & 300 \\
\hline \multicolumn{4}{|l|}{ Voetzoolpositie } \\
\hline Voetbreedtebereik & 70 & Onderkant negeren & 400 \\
\hline Voetdrempel & 30 & Vertikale Afwijking & 110 \\
\hline Teenlengte & 85 & Teenhoek & 33 \\
\hline Verklein Voetgebied & 15 & & \\
\hline \multicolumn{4}{|l|}{ Laesies } \\
\hline Gevoeligheid Rood & 77 & Gevoeligheid Groen & 60 \\
\hline Drempel & 24 & & \\
\hline Negeer heel klein & 79 & Ernstig bij Breedte & 20 \\
\hline Negeer lichtrood & 10 & & \\
\hline \multicolumn{2}{|c|}{ Negeer schaduw bovenaan } & \multicolumn{2}{|c|}{12} \\
\hline & & & \\
\hline \multicolumn{4}{|l|}{ Klassificatie } \\
\hline Score-drempels & Ernst & & Grootte \\
\hline Van 0 naar 1 & 13 & & 280 \\
\hline Van 1 naar 2 & 17 & & 800 \\
\hline \multicolumn{4}{|l|}{ Bloemigheid } \\
\hline Van 2 naar 1 & 11 & & 250 \\
\hline \multicolumn{4}{|l|}{ Aspectratio } \\
\hline Van 1 naar 2 & AAN & & \\
\hline \multicolumn{4}{|l|}{ Extra Beslissing } \\
\hline Als & 13 & $<$ Ernst $<$ & 20 \\
\hline en $->$ dan score $=1$ & 350 & $<$ Grootte $<$ & 1000 \\
\hline \multicolumn{4}{|c|}{ Weegfactoren voor eindscore } \\
\hline Voor Score 1 & 0.5 & Voor Score 1 & 2.0 \\
\hline
\end{tabular}




\section{Bijlage 3 Scorekaart voetzoollaesies vleeskuikens versie 1.3}

Scorekaart voetzoollaesies vleeskuikens (versie 1.3)
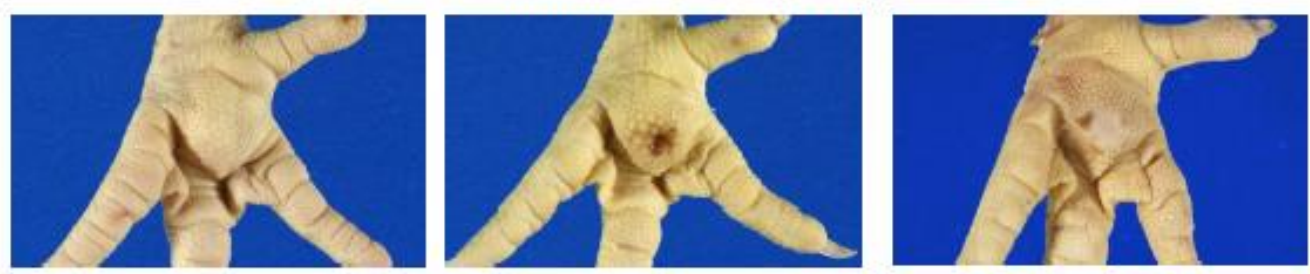

Klasse 0 - glad, geen laesie
Class 0 - smooth, no lesion

Klasse 0-kleine verkleuring

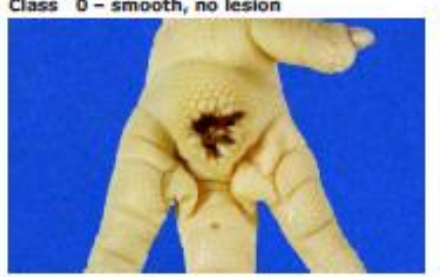

Class 0 - small discolouration

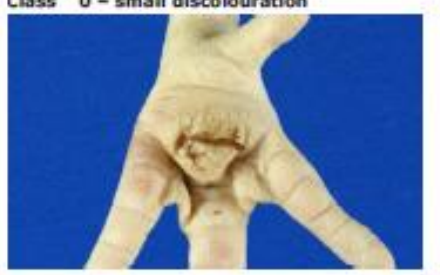

Klasse 0 - (bijna) genezen (litteken) Class 0 - (almost) healed lesion (scar)

Klasse 1 - oppervlakkige laesle, verkleuring

Klasse 1-donkere papillen, geen ontsteking Class 1 -superficial lesion, discolouration
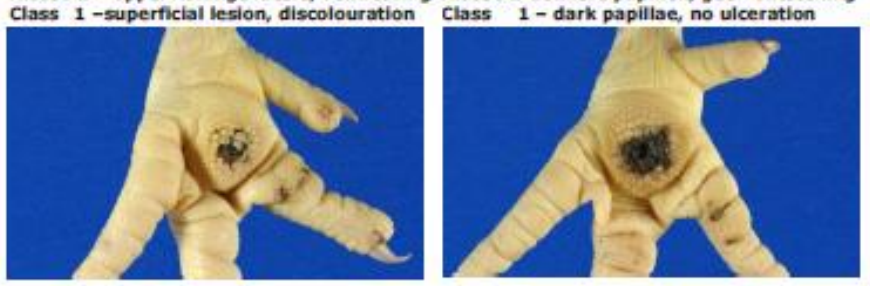

Klasse 2 - donkere papillen en zweer Class 2 - dark papillae and uicer

Klasse 2 - zweer bedekt met korst Class 2 - ulcer covered by crust

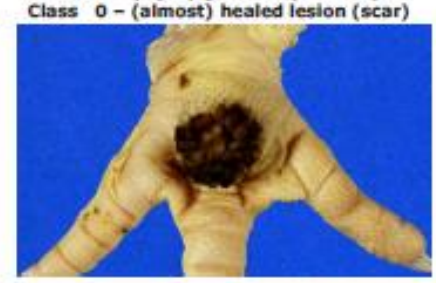

Klasse 1 - aanzientijke verkleuring Class 1 - substantial discolouration

Uitleg scorekaart voetzoollaesies vleeskuikens (Methodiek (Berg) - a photo guide to broiler foot health classification (version 1.3)

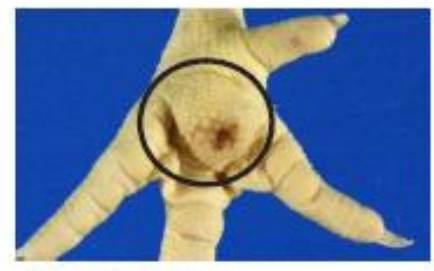

Klasse 0 - geen laesie

Class 0- no lesion

Klasse 0 - Geen laesies: geen laesie of zeekleine en oppervakkige aantasting (geringe verkleuring $c$ een klein oppervak), milde hyperkeratose, (oude) littekens. Opperviakte hyperkeratose, (oude) littekens. Oppervlakte sen ludferkopje.

Alleen de voetzool (amcirkelde deel) wordt meegenomen in de becordeling

Class 0 - No lesion: no lesions or very smal and superficial lesions, slight discolouration on a limited area, mild hyperkeratosis, old scars. Maximum ares discolouration: size of a match head.

Only the foot path (dircled area) should be evaluated.

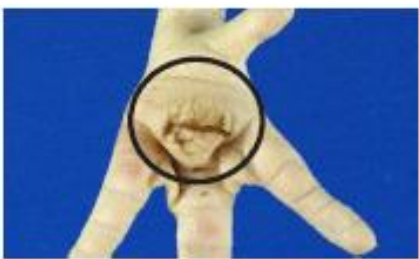

Klasse 1 - milde laesie Class 1 - mild lesion

Klasse 1 - Milde laesie: verkleuring van de voetzod (groter dan een luciferkopje), oppervlakkige aantasting, vergrote en/of verkieurde papillen.

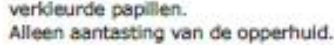

Alleen de voetzool (ameirkelde ded) wordt meegenomen in de beoordeling.

Class 1 - Mild lesion: discolouration of the foot pad (larger than the size of a match head), superficial damage, dark and/or large papillae.

Only the foot path (ainded ares) should be evaluated.

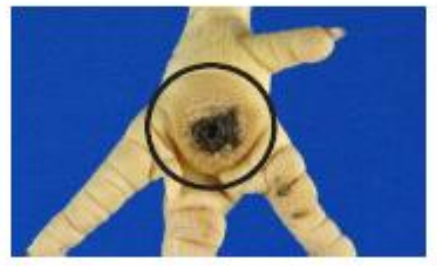

Klasse 2 - ernstige laesie Class 2 - severe lesion

Klasse 2 - Ernstige laesie: zweer met bloedkorsten van enige omvang, (tekenen van) blceduitstortingen of emstig gezwollen voetzolen (abces).

Aantasting tot in de diepere huidlagen.

Alleen de vaetzoof (ancinkeide deef) wordt meegenomen in de beoordering.

Class 2 - Severe lesion: Ulcers with seabs of significant size, signs of haemorrhages or severely swollen foot pad (abscess).

Only the foot path (cirded ares) should be evaluated.
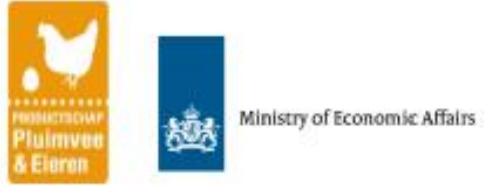


\section{Aanvulling scorekaart voetzoollaesies vleeskuikens (versie 1.3)}

Klasse 0: geen laesies

Voetzolen beoordeeld in klasse 0 (geen laesies) zijn voetzolen die niet of nauwelijks zijn aangetast. Als er sprake is van aantasting betreft het een zeer geringe lichtbruine verkleuring. De grootte van de aantasting bedraagt maximaal de grootte van het kopje van een lucifer. Voetzoollaesies kunnen genezen. Wanneer ze (bijna) volledig genezen zijn vallen ze ook onder klasse 0 , mits de resterende aantasting (verkleuring) kleiner is dan de grootte van een luciferkopje. Genezen voetzoollaesies zijn te herkennen aan de gladde huid (litteken).

Klasse 1: milde laesies

Klasse 1 laesies kunnen in diverse vormen voorkomen (zie scorekaart). De verkleuring verschilt ten opzichte van klasse 0 in de grootte: groter dan een luciferkopje. Ze verschillen van klasse 2 door de diepte van de aantasting: een klasse 1 laesie betreft altijd een oppervlakkige aantasting (alleen aantasting van de opperhuid). Vaak gaat verkleuring van de voetzool samen met hyperkeratose (vergrote papillen); hyperkeratose is altijd klasse 1. Soms is de huid rood en/of (licht) gezwollen.

De aantasting/verkleuring van de voetzool kan zich uitstrekken tot een groot deel van de voetzool, maar als de aantasting oppervlakkig is valt deze altijd onder klasse 1 . De verkleuring kan variëren van lichtbruin tot donkerbruin/bijna zwart.

\section{Klasse 2: ernstige laesies}

Klasse 2 laesies gaan altijd gepaard met een zweer (open wond, afbraak opperhuid) of abces (zwelling met onderhuids pus). Verschil met klasse 1 laesies is dat de aantasting zich niet meer beperkt tot de opperhuid maar tot in de diepere huidlagen is of onderhuids. De aantasting kan klein zijn maar kan ook de hele voetzool beslaan (aantasting kan zich zelfs uitstekken tot de tenen maar deze worden niet meegenomen in de beoordeling). De verkleuring is meestal zeer donkerbruin tot zwart. De zweer is meestal bedekt met een korst.

In het geval van een abces spreken we bij vleeskuikens van een 'bumble foot'. Een abces kan maar hoeft niet samen te gaan met een (kleine) aantasting of verkleuring van de opperhuid. De zwelling is duidelijk herkenbaar en voelt als een 'verharde bal'. 'Bumble foot' komt niet vaak voor bij vleeskuikens. 


\section{Bijlage 4 Scores per klasse}

Tabel B4.1 Scores per klasse gemeten door de WLR-beoordelaar.

\begin{tabular}{|c|c|c|c|c|c|c|c|c|c|c|}
\hline \multirow{2}{*}{$\begin{array}{c}\text { Steek- } \\
\text { proef }\end{array}$} & \multirow[t]{2}{*}{ Koppel } & \multirow[t]{2}{*}{ Broeiwijze $^{1}$} & \multirow{2}{*}{$\begin{array}{c}\text { Gemeten } \\
\text { n }\end{array}$} & \multicolumn{2}{|c|}{ score 0} & \multicolumn{2}{|c|}{ score 1} & \multicolumn{2}{|c|}{ score 2} & \multirow[t]{2}{*}{ FPS } \\
\hline & & & & $\mathbf{n}$ & $\%$ & $\mathbf{n}$ & $\%$ & n & $\%$ & \\
\hline 1 & 1 & LB & 100 & 95 & 95 & 5 & 5 & 0 & 0 & 2,5 \\
\hline 2 & 2 & LB & 100 & 72 & 72 & 17 & 17 & 11 & 11 & 30,5 \\
\hline 3 & 2 & LB & 100 & 72 & 72 & 15 & 15 & 13 & 13 & 33,5 \\
\hline 4 & 2 & LB & 100 & 77 & 77 & 14 & 14 & 9 & 9 & 25,0 \\
\hline 5 & 3 & LB & 100 & 29 & 29 & 70 & 70 & 1 & 1 & 37,0 \\
\hline 6 & 3 & LB & 100 & 45 & 45 & 54 & 54 & 1 & 1 & 29,0 \\
\hline 7 & 3 & LB & 100 & 44 & 44 & 53 & 53 & 3 & 3 & 32,5 \\
\hline 8 & 4 & LB & 100 & 39 & 39 & 48 & 48 & 13 & 13 & 50,0 \\
\hline 9 & 4 & LB & 100 & 41 & 41 & 50 & 50 & 9 & 9 & 43,0 \\
\hline 10 & 4 & LB & 100 & 39 & 39 & 44 & 44 & 17 & 17 & 56,0 \\
\hline 11 & 4 & LB & 100 & 38 & 38 & 49 & 49 & 13 & 13 & 50,5 \\
\hline 12 & 5 & LB & 100 & 30 & 30 & 19 & 19 & 51 & 51 & 111,5 \\
\hline 13 & 5 & LB & 100 & 46 & 46 & 16 & 16 & 38 & 38 & 84,0 \\
\hline 14 & 5 & LB & 100 & 23 & 23 & 20 & 20 & 57 & 57 & 124,0 \\
\hline 15 & 6 & LB & 100 & 62 & 62 & 13 & 13 & 25 & 25 & 56,5 \\
\hline 16 & 6 & HB & 100 & 40 & 40 & 29 & 29 & 31 & 31 & 76,5 \\
\hline 17 & 6 & $\mathrm{HB}$ & 100 & 52 & 52 & 19 & 19 & 29 & 29 & 67,5 \\
\hline 18 & 6 & $\mathrm{HB}$ & 100 & 45 & 45 & 29 & 29 & 26 & 26 & 66,5 \\
\hline 19 & 7 & $\mathrm{HB}$ & 100 & 27 & 27 & 15 & 15 & 58 & 58 & 123,5 \\
\hline 20 & 7 & $\mathrm{HB}$ & 90 & 34 & 38 & 19 & 21 & 37 & 41 & 92,8 \\
\hline 21 & 8 & LB & 100 & 96 & 96 & 4 & 4 & 0 & 0 & 2,0 \\
\hline 22 & 9 & LB & 100 & 8 & 8 & 10 & 10 & 82 & 82 & 169,0 \\
\hline 23 & 9 & LB & 100 & 4 & 4 & 9 & 9 & 87 & 87 & 178,5 \\
\hline 24 & 10 & LB & 100 & 21 & 21 & 17 & 17 & 62 & 62 & 132,5 \\
\hline 25 & 10 & LB & 100 & 22 & 22 & 16 & 16 & 62 & 62 & 132,0 \\
\hline 26 & 11 & LB & 100 & 9 & 9 & 4 & 4 & 87 & 87 & 176,0 \\
\hline 27 & 12 & LB & 100 & 98 & 98 & 2 & 2 & 0 & 0 & 1,0 \\
\hline 28 & 12 & $\mathrm{HB}$ & 100 & 98 & 98 & 2 & 2 & 0 & 0 & 1,0 \\
\hline 29 & 13 & $\mathrm{HB}$ & 100 & 22 & 22 & 7 & 7 & 71 & 71 & 145,5 \\
\hline 30 & 13 & $\mathrm{HB}$ & 100 & 23 & 23 & 16 & 16 & 61 & 61 & 130,0 \\
\hline 31 & 14 & $\mathrm{HB}$ & 100 & 85 & 85 & 12 & 12 & 3 & 3 & 12,0 \\
\hline 32 & 15 & $\mathrm{HB}$ & 100 & 78 & 78 & 13 & 13 & 9 & 9 & 24,5 \\
\hline 33 & 16 & $\mathrm{HB}$ & 100 & 99 & 99 & 1 & 1 & 0 & 0 & 0,5 \\
\hline 34 & 17 & $\mathrm{HB}$ & 100 & 8 & 8 & 9 & 9 & 83 & 83 & 170,5 \\
\hline 35 & 18 & $\mathrm{HB}$ & 100 & 4 & 4 & 13 & 13 & 83 & 83 & 172,5 \\
\hline
\end{tabular}

\footnotetext{
$1 \mathrm{LB}=$ laagbroei; $\mathrm{HB}=$ hoogbroei
} 
Tabel B4.2 Scores per klasse gemeten door het camerasysteem.

\begin{tabular}{|c|c|c|c|c|c|c|c|c|c|c|c|c|c|}
\hline \multirow[t]{2}{*}{ Meting } & \multirow[t]{2}{*}{ Koppel } & \multirow{2}{*}{$\begin{array}{l}\text { Broei- } \\
\text { wijze }^{1}\end{array}$} & \multirow{2}{*}{$\begin{array}{c}\text { Totaal } \\
\text { n }\end{array}$} & \multirow{2}{*}{$\begin{array}{c}\text { Gemeten } \\
\text { n }\end{array}$} & \multicolumn{2}{|c|}{$\begin{array}{c}\text { Niet } \\
\text { gemeten }\end{array}$} & \multicolumn{2}{|c|}{ score 0} & \multicolumn{2}{|c|}{ score 1} & \multicolumn{2}{|c|}{ score 2} & \multirow[t]{2}{*}{ FPS } \\
\hline & & & & & n & $\%$ & $\mathbf{n}$ & $\%$ & $\mathbf{n}$ & $\%$ & $\mathbf{n}$ & $\%$ & \\
\hline 1 & 1 & LB & 393 & 392 & 1 & 0,3 & 351 & 89,5 & 27 & 6,9 & 14 & 3,6 & 10,6 \\
\hline 2 & 2 & LB & 373 & 371 & 2 & 0,5 & 235 & 63,3 & 98 & 26,4 & 38 & 10,2 & 33,7 \\
\hline 3 & 2 & LB & 393 & 392 & 1 & 0,3 & 255 & 65,1 & 106 & 27,0 & 31 & 7,9 & 29,3 \\
\hline 4 & 2 & LB & 358 & 356 & 2 & 0,6 & 238 & 66,9 & 92 & 25,8 & 26 & 7,3 & 27,5 \\
\hline 5 & 3 & LB & 392 & 387 & 5 & 1,3 & 136 & 35,1 & 189 & 48,8 & 62 & 16,0 & 56,5 \\
\hline 6 & 3 & LB & 372 & 369 & 3 & 0,8 & 142 & 38,5 & 160 & 43,4 & 67 & 18,2 & 58,0 \\
\hline 7 & 3 & LB & 367 & 365 & 2 & 0,5 & 138 & 37,8 & 170 & 46,6 & 57 & 15,6 & 54,5 \\
\hline 8 & 4 & LB & 412 & 412 & 0 & 0,0 & 145 & 35,2 & 135 & 32,8 & 132 & 32,0 & 80,5 \\
\hline 9 & 4 & LB & 374 & 373 & 1 & 0,3 & 129 & 34,6 & 169 & 45,3 & 75 & 20,1 & 62,9 \\
\hline 10 & 4 & LB & 414 & 413 & 1 & 0,2 & 136 & 32,9 & 150 & 36,3 & 127 & 30,8 & 79,7 \\
\hline 11 & 4 & LB & 371 & 368 & 3 & 0,8 & 132 & 35,9 & 89 & 24,2 & 147 & 39,9 & 92,0 \\
\hline 12 & 5 & LB & 372 & 371 & 1 & 0,3 & 126 & 34,0 & 106 & 28,6 & 139 & 37,5 & 89,2 \\
\hline 13 & 5 & LB & 345 & 343 & 2 & 0,6 & 140 & 40,8 & 84 & 24,5 & 119 & 34,7 & 81,6 \\
\hline 14 & 5 & LB & 441 & 440 & 1 & 0,2 & 99 & 22,5 & 124 & 28,2 & 217 & 49,3 & 112,7 \\
\hline 15 & 6 & LB & 438 & 437 & 1 & 0,2 & 212 & 48,5 & 121 & 27,7 & 104 & 23,8 & 61,4 \\
\hline 16 & 6 & $\mathrm{HB}$ & 442 & 439 & 3 & 0,7 & 176 & 40,1 & 114 & 26,0 & 149 & 33,9 & 80,9 \\
\hline 17 & 6 & $\mathrm{HB}$ & 423 & 423 & 0 & 0,0 & 160 & 37,8 & 116 & 27,4 & 147 & 34,8 & 83,2 \\
\hline 18 & 6 & $\mathrm{HB}$ & 344 & 343 & 1 & 0,3 & 170 & 49,6 & 79 & 23,0 & 94 & 27,4 & 66,3 \\
\hline 19 & 7 & $\mathrm{HB}$ & 412 & 408 & 4 & 1,0 & 117 & 28,7 & 97 & 23,8 & 194 & 47,5 & 107,0 \\
\hline 20 & 7 & $\mathrm{HB}$ & 376 & 375 & 1 & 0,3 & 133 & 35,5 & 87 & 23,2 & 155 & 41,3 & 94,3 \\
\hline 21 & 8 & LB & 389 & 375 & 14 & 3,6 & 332 & 88,5 & 30 & 8,0 & 13 & 3,5 & 10,9 \\
\hline 22 & 9 & LB & 331 & 328 & 3 & 0,9 & 23 & 7,0 & 60 & 18,3 & 245 & 74,7 & 158,5 \\
\hline 23 & 9 & LB & 447 & 440 & 7 & 1,6 & 23 & 5,2 & 60 & 13,6 & 357 & 81,1 & 169,1 \\
\hline 24 & 10 & LB & 400 & 394 & 6 & 1,5 & 85 & 21,6 & 86 & 21,8 & 223 & 56,6 & 124,1 \\
\hline 25 & 10 & LB & 380 & 376 & 4 & 1,1 & 59 & 15,7 & 107 & 28,5 & 210 & 55,9 & 125,9 \\
\hline 26 & 11 & LB & 348 & 348 & 0 & 0,0 & 14 & 4,0 & 43 & 12,4 & 291 & 83,6 & 173,4 \\
\hline 27 & 12 & LB & 398 & 389 & 9 & 2,3 & 349 & 89,7 & 30 & 7,7 & 10 & 2,6 & 9,0 \\
\hline 28 & 12 & $\mathrm{HB}$ & 330 & 325 & 5 & 1,5 & 272 & 83,7 & 40 & 12,3 & 13 & 4,0 & 14,2 \\
\hline 29 & 13 & $\mathrm{HB}$ & 337 & 335 & 2 & 0,6 & 43 & 12,8 & 47 & 14,0 & 245 & 73,1 & 153,3 \\
\hline 30 & 13 & $\mathrm{HB}$ & 297 & 296 & 1 & 0,3 & 78 & 26,4 & 40 & 13,5 & 178 & 60,1 & 127,0 \\
\hline 31 & 14 & $\mathrm{HB}$ & 497 & 485 & 12 & 2,4 & 339 & 69,9 & 102 & 21,0 & 44 & 9,1 & 28,7 \\
\hline 32 & 15 & $\mathrm{HB}$ & 361 & 351 & 10 & 2,8 & 245 & 69,8 & 72 & 20,5 & 34 & 9,7 & 29,6 \\
\hline 33 & 16 & $\mathrm{HB}$ & 404 & 396 & 8 & 2,0 & 338 & 85,4 & 38 & 9,6 & 20 & 5,1 & 14,9 \\
\hline 34 & 17 & $\mathrm{HB}$ & 409 & 399 & 10 & 2,4 & 44 & 11,0 & 63 & 15,8 & 292 & 73,2 & 154,3 \\
\hline 35 & 18 & $\mathrm{HB}$ & 346 & 330 & 16 & 4,6 & 14 & 4,2 & 29 & 8,8 & 287 & 87,0 & 178,3 \\
\hline
\end{tabular}

1 LB= laagbroei; HB= hoogbroei 


\section{Bijlage 5 Correlatie per scoringsklasse (o.b.v. steekproef)}

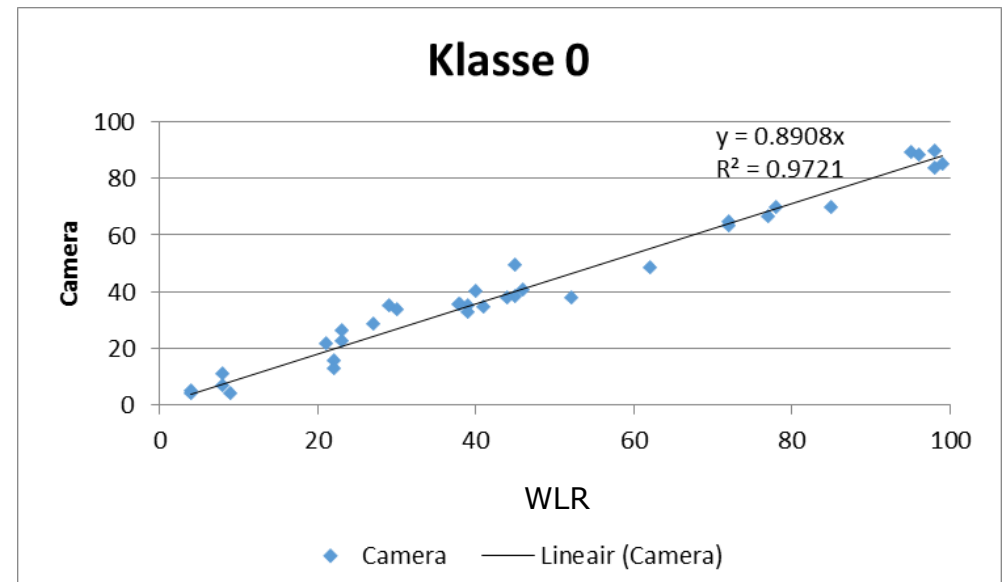

Figuur B5.1 Correlatie camera en getrainde WLR-beoordelaar in klasse 0 (geen laesie) o.b.v. alle genomen steekproeven. De zwarte lijn geeft de situatie bij 100\% overeenkomst tussen camera en WLR-beoordelaar weer.

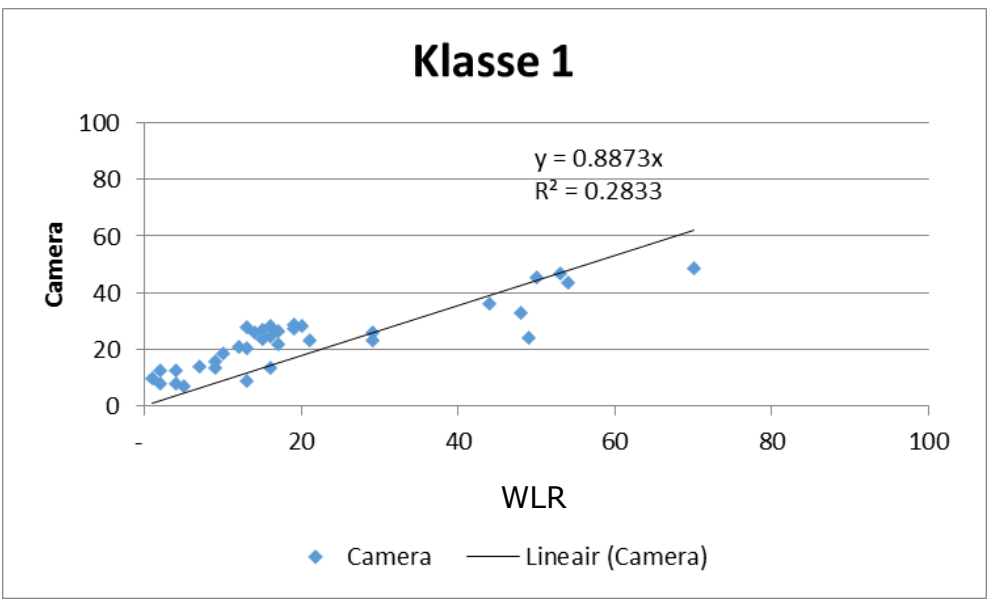

Figuur B5. 2 Correlatie camera en getrainde WLR-beoordelaar in klasse 1 (milde laesie) o.b.v. alle genomen steekproeven. De zwarte lijn geeft de situatie bij $100 \%$ overeenkomst tussen camera en WLR-beoordelaar weer.

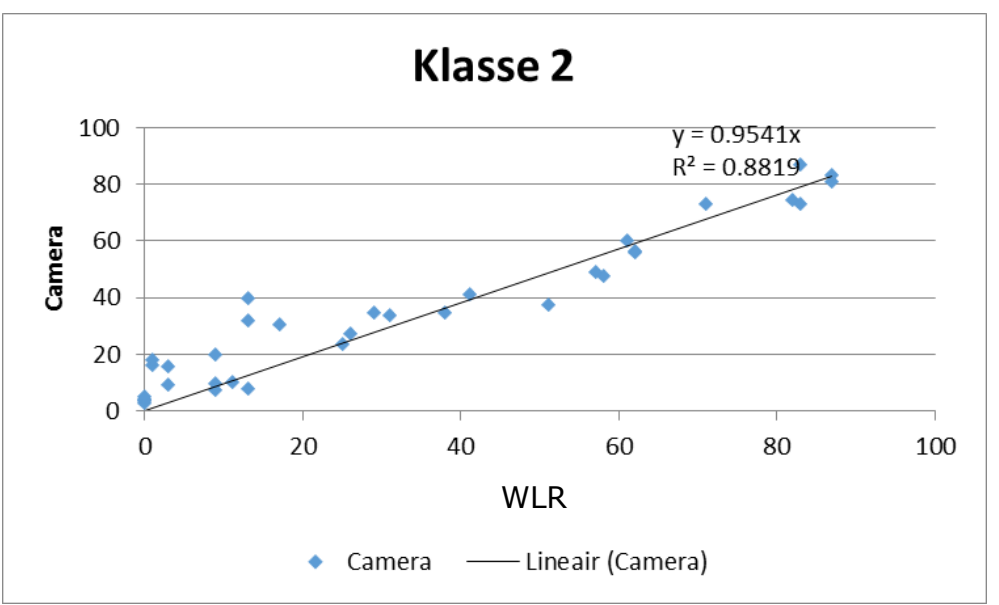

Figuur B5.3 Correlatie camera en getrainde WLR-beoordelaar in klasse 2 (ernstige laesie) o.b.v. alle genomen steekproeven. De zwarte lijn geeft de situatie bij $100 \%$ overeenkomst tussen camera en WLR-beoordelaar weer. 


\section{Bijlage 6 Behaalde voetzoollaesiescores per steekproef en koppelniveau}

Tabel B6.1 Voetzoollaesiescores WLR en camerasysteem per meting/steekproef.

\begin{tabular}{|c|c|c|c|c|c|}
\hline Meting & Koppel & Broei & WLR & Camera & Verschil \\
\hline 1 & 1 & Laagbroei & 3 & 11 & 8 \\
\hline 2 & 2 & Laagbroei & 31 & 34 & 3 \\
\hline 3 & 2 & Laagbroei & 34 & 29 & -4 \\
\hline 4 & 2 & Laagbroei & 25 & 28 & 3 \\
\hline 5 & 3 & Laagbroei & 37 & 56 & 19 \\
\hline 6 & 3 & Laagbroei & 29 & 58 & 29 \\
\hline 7 & 3 & Laagbroei & 33 & 55 & 22 \\
\hline 8 & 4 & Laagbroei & 50 & 80 & 30 \\
\hline 9 & 4 & Laagbroei & 43 & 63 & 20 \\
\hline 10 & 4 & Laagbroei & 56 & 80 & 24 \\
\hline 11 & 4 & Laagbroei & 51 & 92 & 41 \\
\hline 12 & 5 & Laagbroei & 112 & 89 & -22 \\
\hline 13 & 5 & Laagbroei & 84 & 82 & -2 \\
\hline 14 & 5 & Laagbroei & 124 & 113 & -11 \\
\hline 15 & 6 & Laagbroei & 57 & 61 & 5 \\
\hline 16 & 6 & Hoogbroei & 77 & 81 & 4 \\
\hline 17 & 6 & Hoogbroei & 68 & 83 & 16 \\
\hline 18 & 6 & Hoogbroei & 67 & 66 & 0 \\
\hline 19 & 7 & Hoogbroei & 124 & 107 & -17 \\
\hline 20 & 7 & Hoogbroei & 93 & 94 & 1 \\
\hline 21 & 8 & Laagbroei & 2 & 11 & 9 \\
\hline 22 & 9 & Laagbroei & 169 & 159 & -10 \\
\hline 23 & 9 & Laagbroei & 179 & 169 & -9 \\
\hline 24 & 10 & Laagbroei & 133 & 124 & -8 \\
\hline 25 & 10 & Laagbroei & 132 & 126 & -6 \\
\hline 26 & 11 & Laagbroei & 176 & 173 & -3 \\
\hline 27 & 12 & Laagbroei & 1 & 9 & 8 \\
\hline 28 & 12 & Hoogbroei & 1 & 14 & 13 \\
\hline 29 & 13 & Hoogbroei & 146 & 153 & 8 \\
\hline 30 & 13 & Hoogbroei & 130 & 127 & -3 \\
\hline 31 & 14 & Hoogbroei & 12 & 29 & 17 \\
\hline 32 & 15 & Hoogbroei & 25 & 30 & 5 \\
\hline 33 & 16 & Hoogbroei & 1 & 15 & 14 \\
\hline 34 & 17 & Hoogbroei & 171 & 154 & -16 \\
\hline 35 & 18 & Hoogbroei & 173 & 178 & 6 \\
\hline
\end{tabular}


Tabel B6.2 Voetzoollaesiescores WLR en camerasysteem per koppel.

\begin{tabular}{|c|c|c|c|}
\hline Koppel & WLR & Camera & Verschil Camera-WLR \\
\hline 1 & 3 & 11 & 8 \\
\hline 2 & 30 & 30 & 1 \\
\hline 3 & 33 & 56 & 23 \\
\hline 4 & 50 & 79 & 29 \\
\hline 5 & 107 & 95 & -12 \\
\hline 6 & 67 & 73 & 6 \\
\hline 7 & 108 & 101 & -8 \\
\hline 8 & 2 & 11 & 9 \\
\hline 9 & 174 & 164 & -10 \\
\hline 10 & 132 & 125 & -7 \\
\hline 11 & 176 & 173 & -3 \\
\hline 12 & 1 & 12 & 11 \\
\hline 13 & 138 & 140 & 2 \\
\hline 14 & 12 & 29 & 17 \\
\hline 15 & 25 & 30 & 5 \\
\hline 16 & 1 & 15 & 14 \\
\hline 17 & 171 & 154 & -16 \\
\hline 18 & 173 & 178 & 6 \\
\hline
\end{tabular}




\section{Bijlage 7 Voetzoollaesiescores per steekproef}

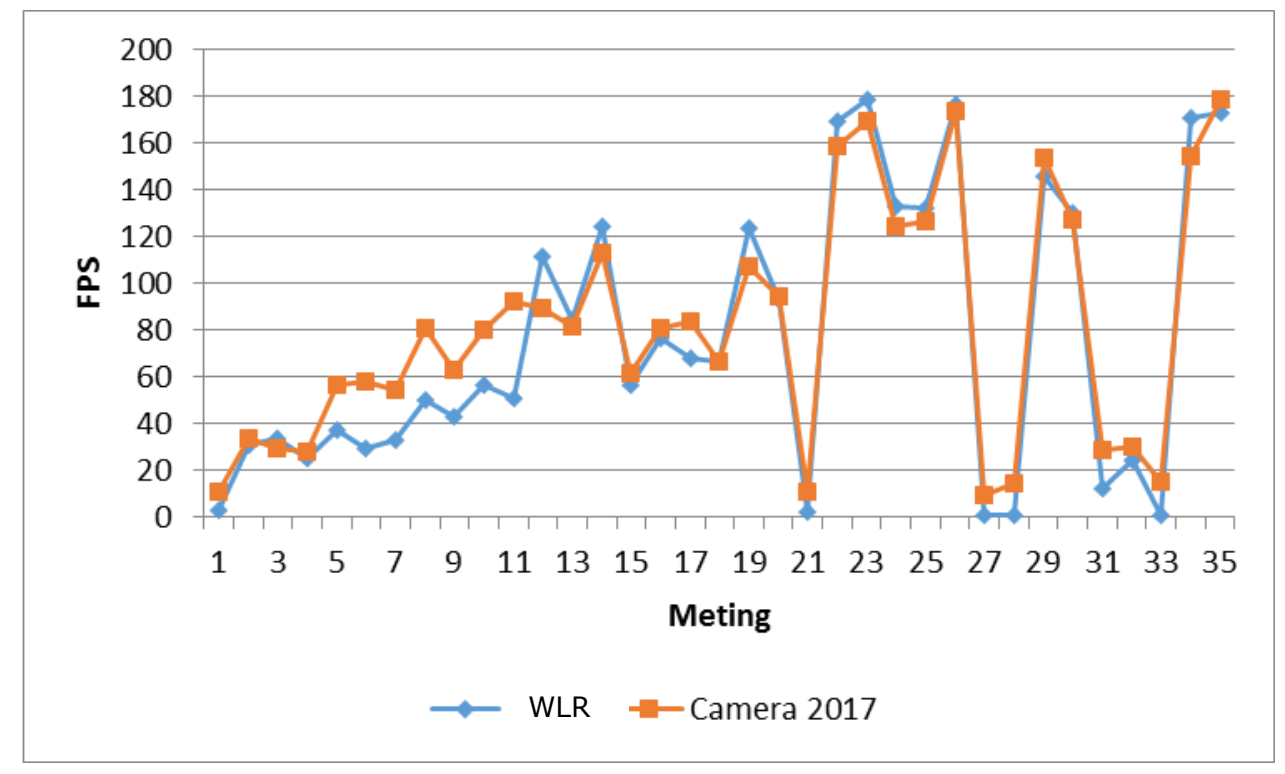

Figuur B7.1 Grafische weergave van de verschillen in voetzoollaesiescore (FPS) per streekproef tussen het camerasysteem en de getrainde WLR-beoordelaar.

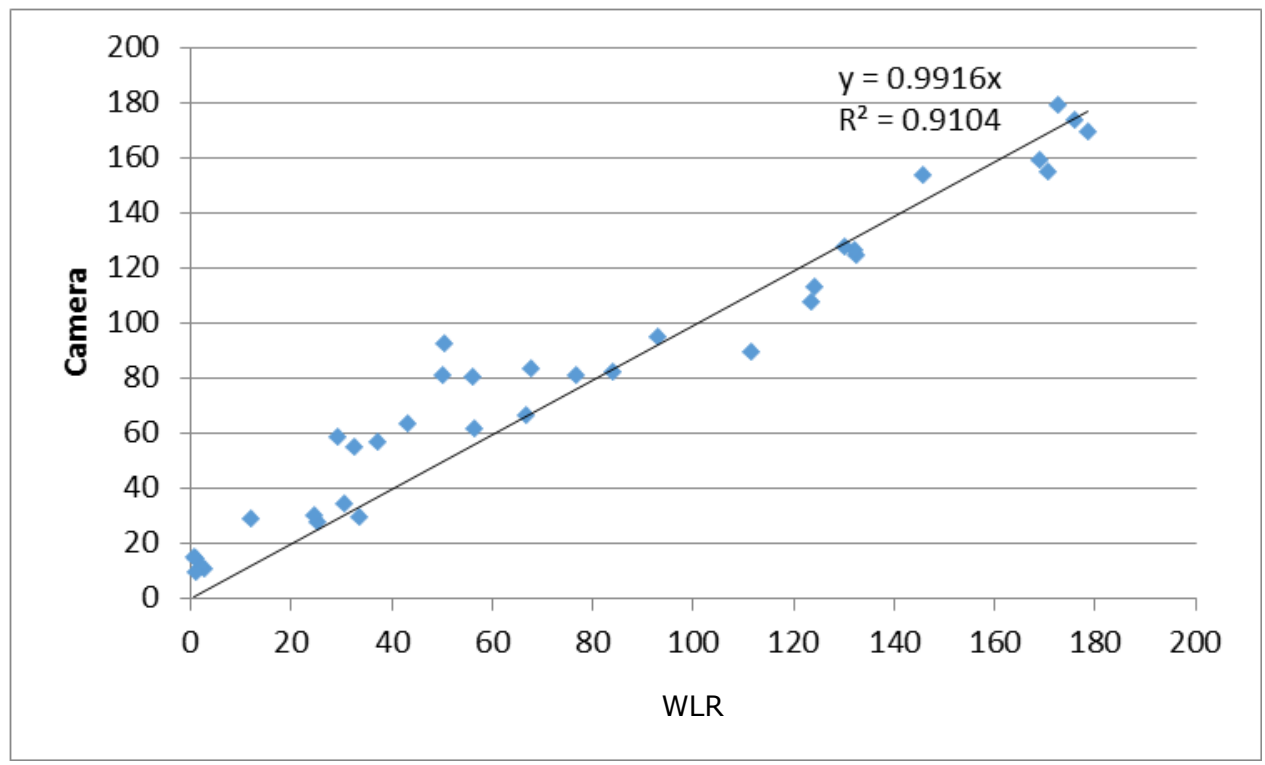

Figuur B7.2 Relatie tussen de voetzoollaesiescores (FPS) per steekproef gegeven door de camera en de getrainde WLR-beoordelaar. De zwarte lijn geeft de situatie bij 100\% overeenkomst tussen camera en WLR-beoordelaar weer. 


\section{Bijlage 8 Voorbeelden van foutief gemeten beelden}

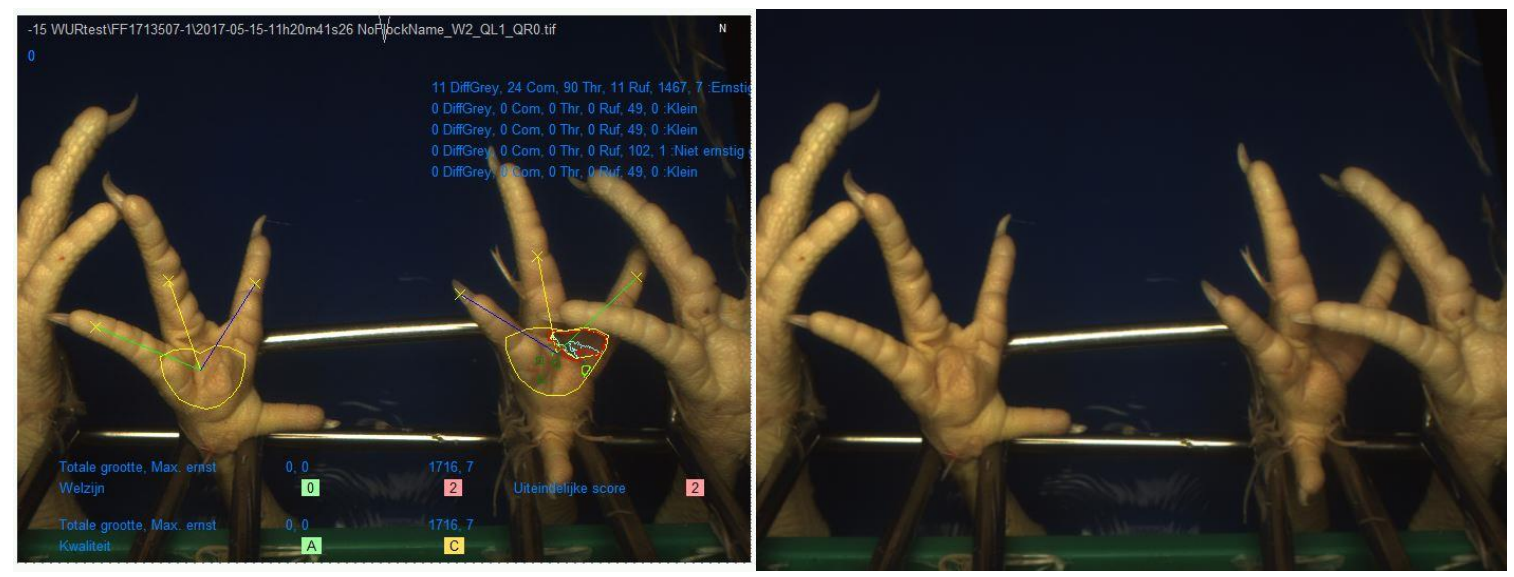

Teen van een ander kuiken
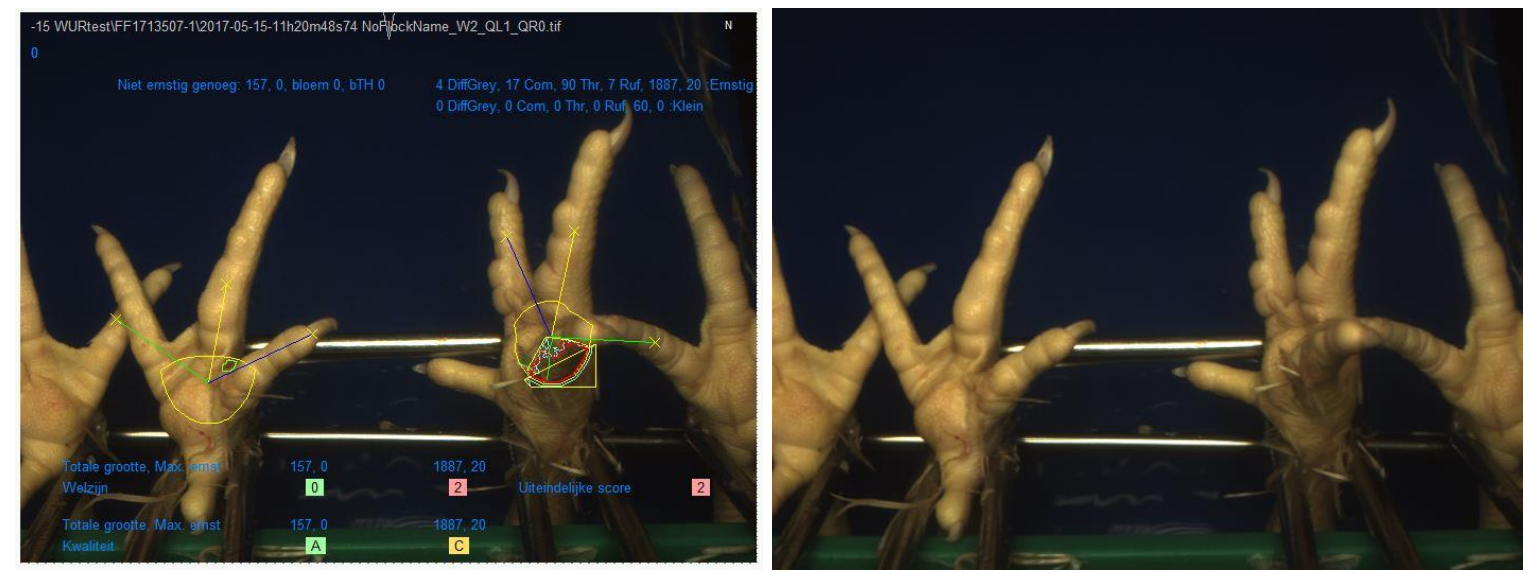

Poot gedraaid + teen ander kuiken
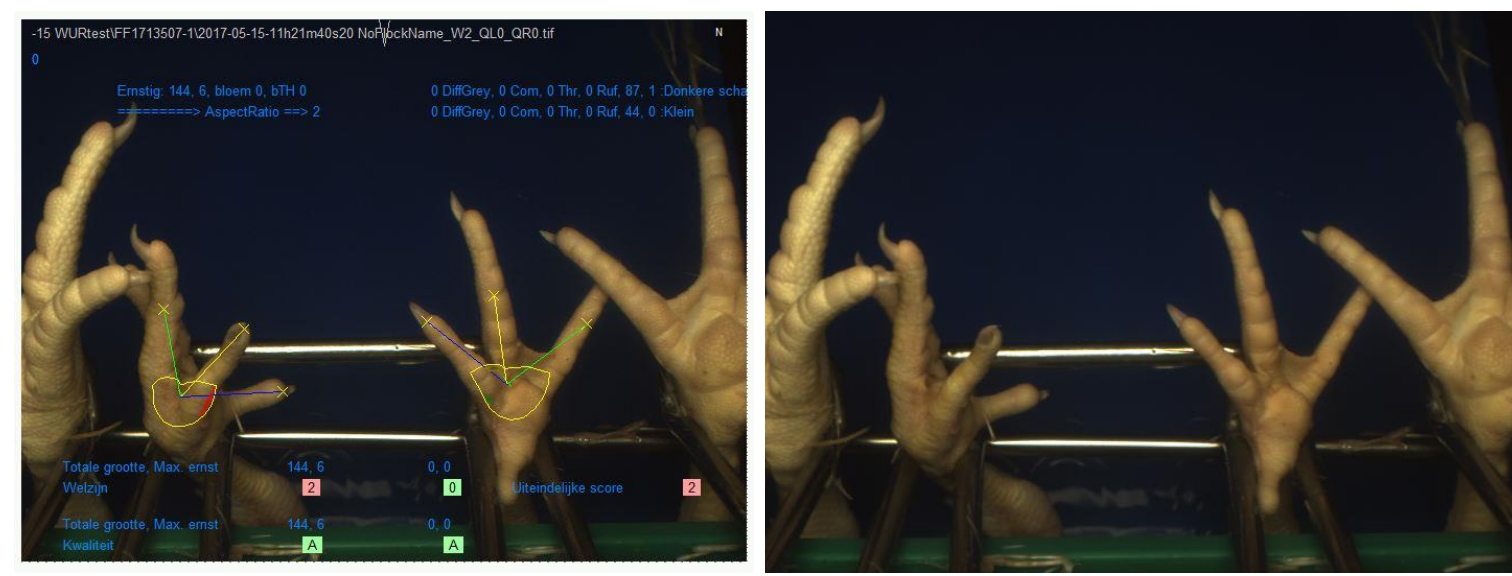

Poot gedraaid 

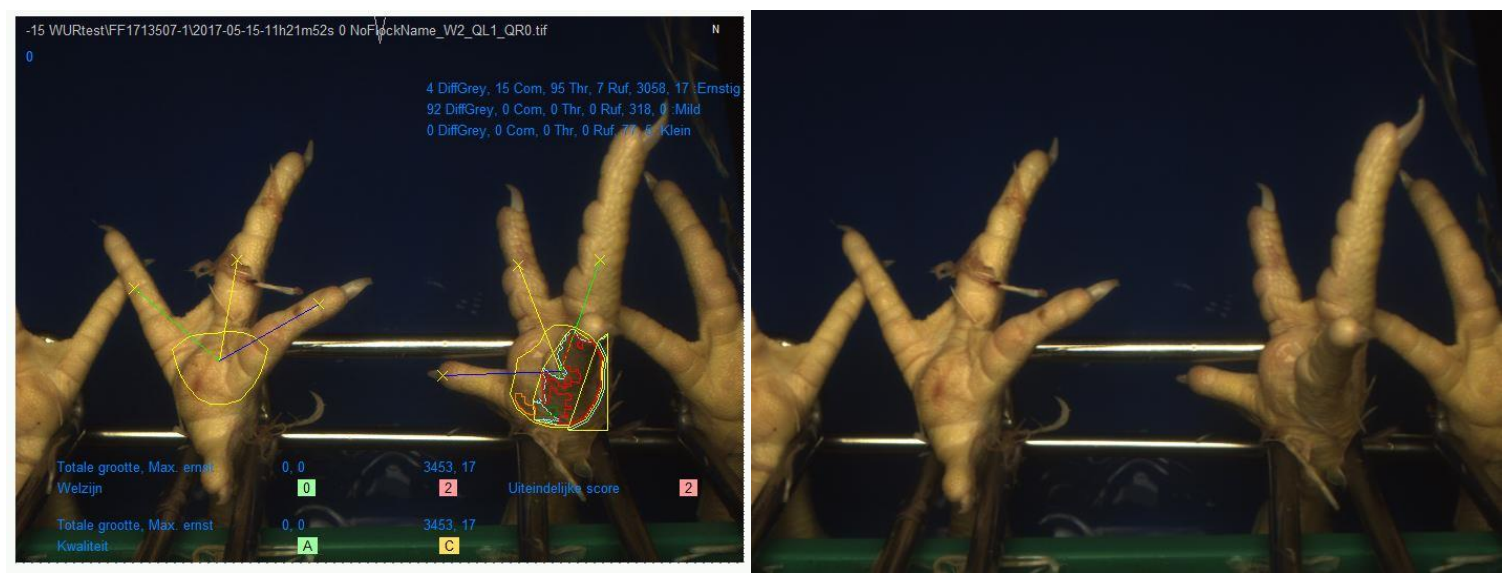

Poot gedraaid, teen gemeten
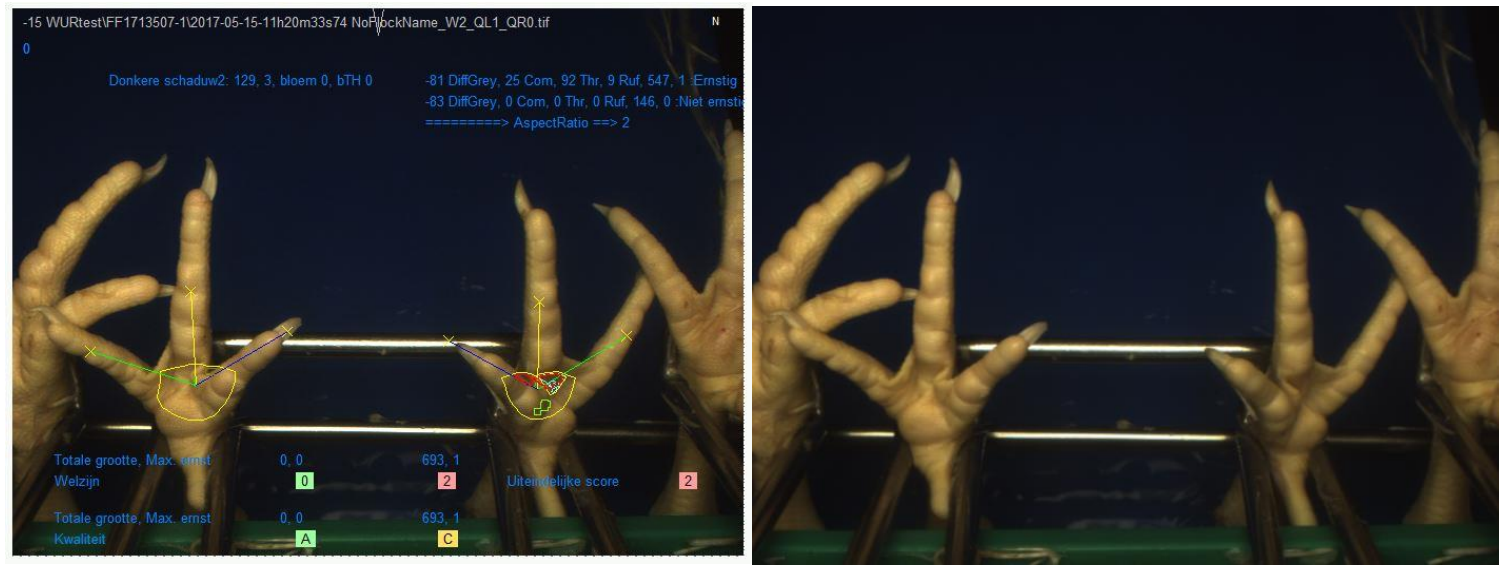

Poot gedraaid, schaduw tussen tenen gemeten

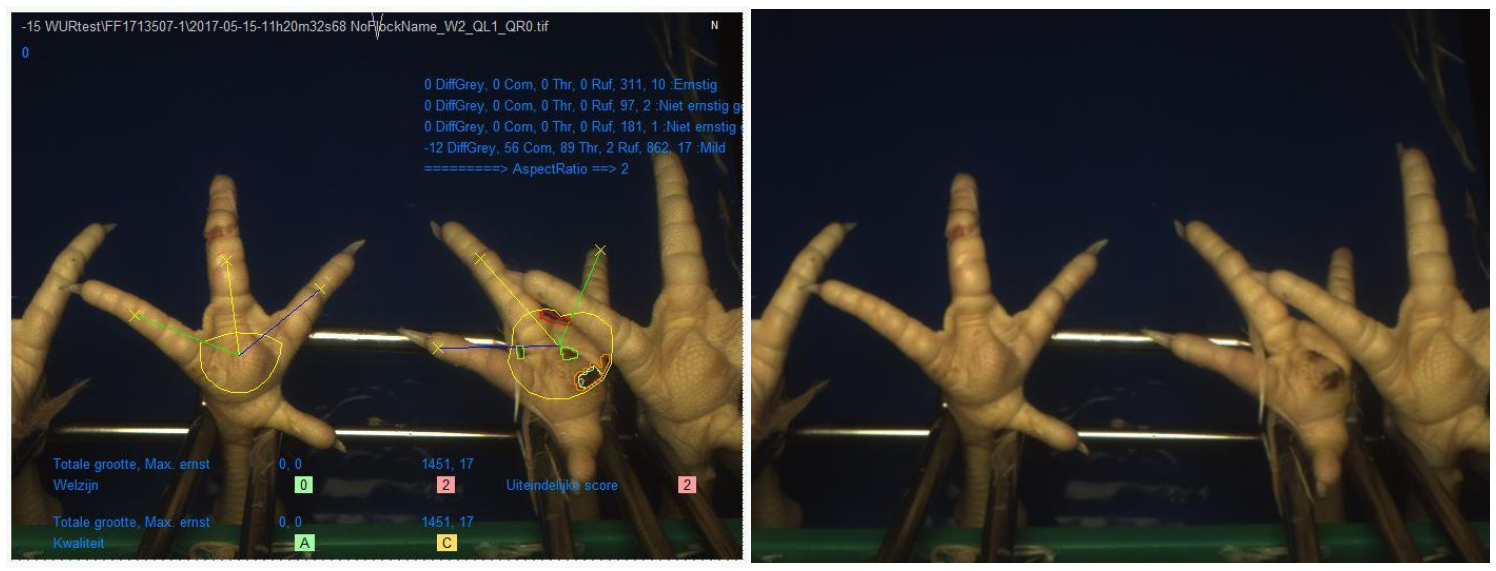

Teen andere kuiken in beeld, verkeerd meetgebied, schaduw achtergrond gemeten 


\section{Bijlage 9 Correlatie per scoringsklasse (o.b.v. steekproef)}

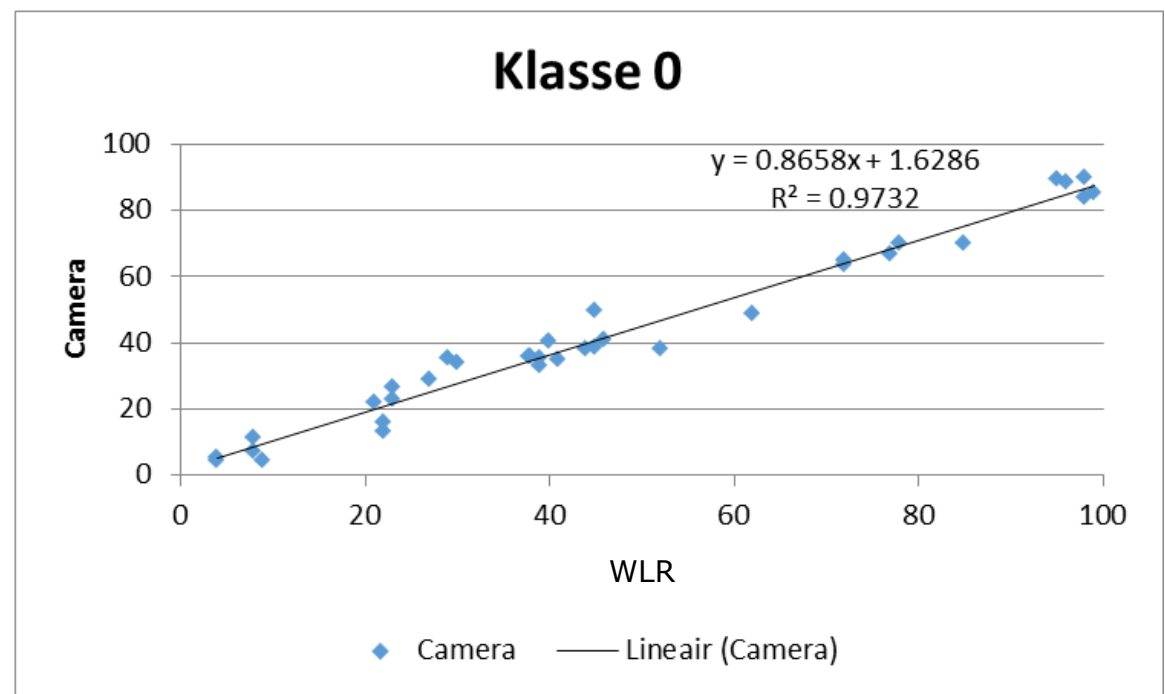

Figuur B9.1 Correlatie camera en getrainde WLR-beoordelaar in klasse 0 (geen laesie). De assen geven het percentage pootjes weer gescoord door WLR of de camera in klasse 0 (per steekproef). De zwarte lijn geeft de situatie bij 100\% overeenkomst tussen camera en WLR-beoordelaar weer.

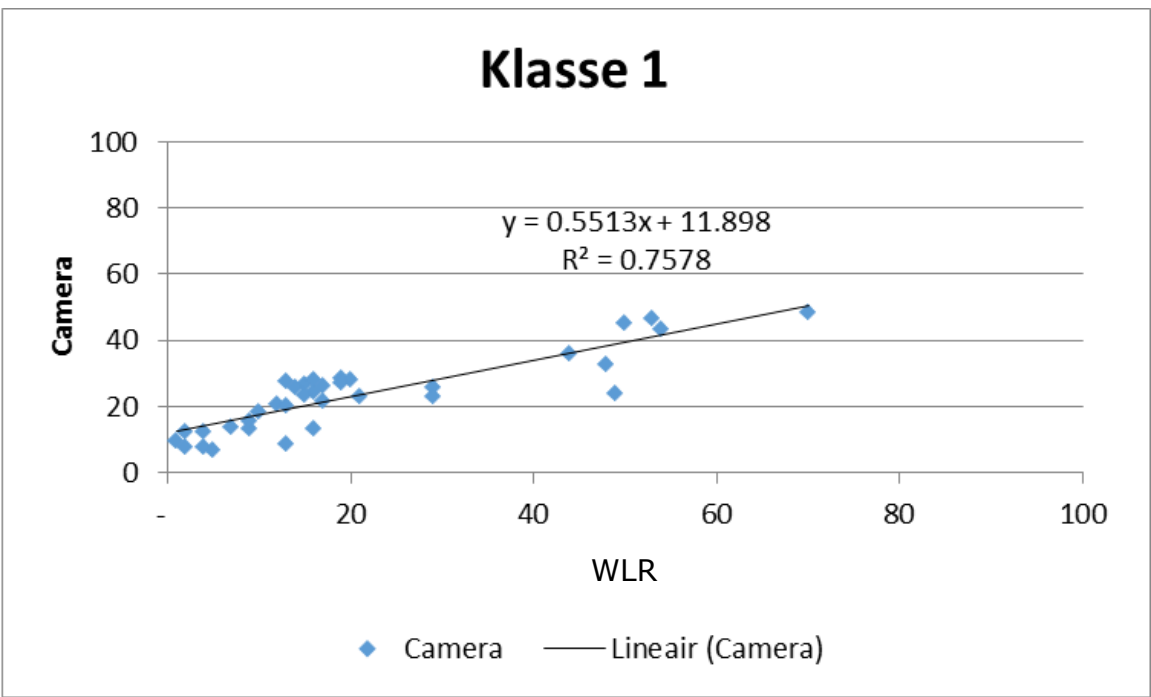

Figuur B9. 2 Correlatie camera en getrainde WLR-beoordelaar in klasse 1 (milde laesie). De assen geven het percentage pootjes weer gescoord door WLR of de camera in klasse 1 (per steekproef). De zwarte lijn geeft de situatie bij 100\% overeenkomst tussen camera en WLR-beoordelaar weer. 


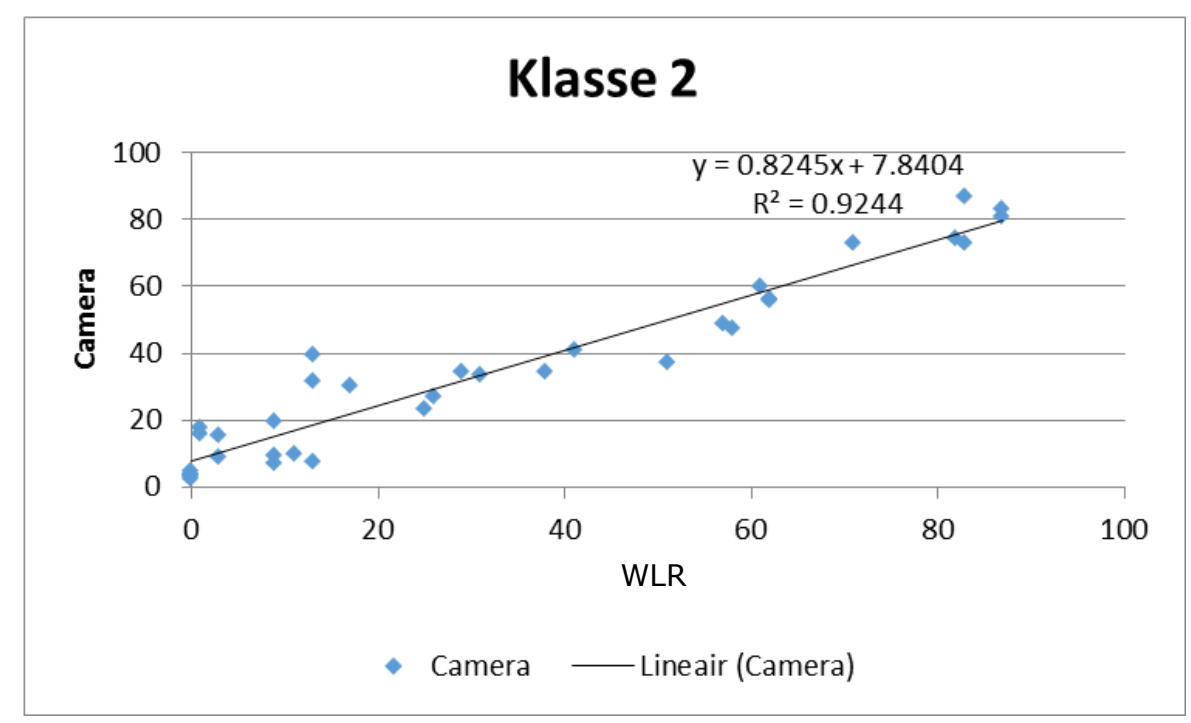

Figuur B9.3 Correlatie camera en getrainde WLR-beoordelaar in klasse 2 (ernstige laesie). De assen geven het percentage pootjes weer gescoord door WLR of de camera in klasse 2 (per steekproef). De zwarte lijn geeft de situatie bij 100\% overeenkomst tussen camera en WLR-beoordelaar weer. 


\section{Bijlage 10 Correlatie voetzoollaesiescore (o.b.v. steekproef)}

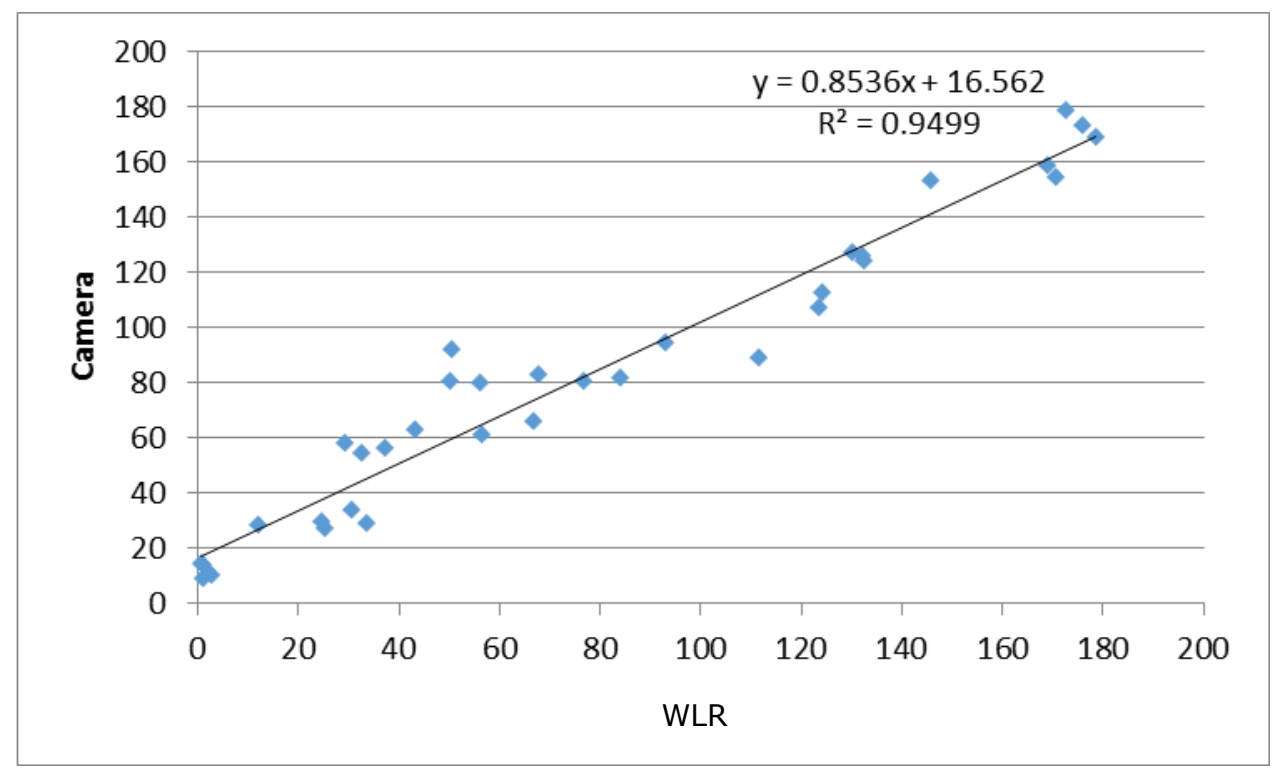

Figuur B10.1 Relatie tussen de voetzoollaesiescores (FPS) per steekproef gegeven door de camera en de getrainde WLR-beoordelaar. De zwarte lijn geeft de situatie bij 100\% overeenkomst tussen camera en WLR-beoordelaar weer. 


\section{Bijlage 11 Statistische analyse}

\section{Camerasysteem versus handmatige meting}

In tabel B11.1 in deze bijlage staan de geschatte parameters van de regressielijn, waaruit de bias (systematische afwijking van het camerasysteem) volgt. Voor de situatie van laagbroei geldt bij een referentietotaalscore $=0$ een overschatting van 11,6 . Het intercept van de bias-lijn wijkt daarmee significant af van 0 . Deze overschatting lijkt ( $p$-waarde van de toets voor het verschil met laagbroei is 0,07$)$ bij hoogbroei nog groter, en wordt geschat op $17,3(11,6+5,7)$.

De bias neemt aanvankelijk af naarmate de referentiescore groter dan 0 is. Dit komt doordat de regressie-coëfficiënt van de bias-lijn met de waarde 0,86 significant kleiner dan 1 is. Uiteindelijk levert dit een negatieve bias bij relatief hogere referentiescores (vanaf referentie_totaalscore van 83 (laagbroei) of 124 (hoogbroei).

Tabel B11.1 Geschatte parameters voor de bias (systematische afwijking t.o.v. de referentietotaalscore).

\begin{tabular}{lcccc} 
Parameter & Schatting & Se & Statistische toets & P-waarde van de \\
toets & $\beta_{0, i=1}=0$ & $\Delta \beta_{0, i=2}=0$ & $<0,01$ \\
Intercept laagbroei & 11,6 & 3,6 & 0,9 & $<0,10$ \\
\hline $\begin{array}{l}\text { Verschil in } \\
\text { intercept voor }\end{array}$ & 5,7 & & $\beta_{1}=1$ & $<0,01$ \\
$\begin{array}{l}\text { hoogbroei (t.o.v. } \\
\text { laagbroei) }\end{array}$ & 0,86 & 0,04 & \\
\hline $\begin{array}{l}\text { Regressie- } \\
\text { coefficient }\end{array}$ & & &
\end{tabular}

In figuur B11.1 is de regressielijn van de bias gevisualiseerd voor beide situaties (laagbroei en hoogbroei). In de figuren is ook de lijn $y=x$ opgenomen. De bias (systematisch fout) is de verschil in de $y$-as-waarde tussen beide lijnen. Dit verschil is dus afhankelijk van het niveau van de referentiescore.

In figuur B11.1 zien we naast de bias ook de individuele afwijkingen van de waarnemingen t.o.v. de bias-lijn. Dit geeft een beeld van de (random) onnauwkeurigheid. Het valt op dat de camerascore rond de referentiescore $=50$ vrijwel allemaal positief afwijken en dat hier alleen informatie van broeiwijze laagbroei is. Echter, deze zeven waarnemingen met een positieve afwijking van de steekproef bij laagbroei, zijn waarnemingen van hetzelfde herkomstbedrijf (verdeeld over 2 koppels).

Hierdoor hebben we de indruk dat de random afwijkingen (onnauwkeurigheid) een sterke bedrijfsgebonden component heeft. 


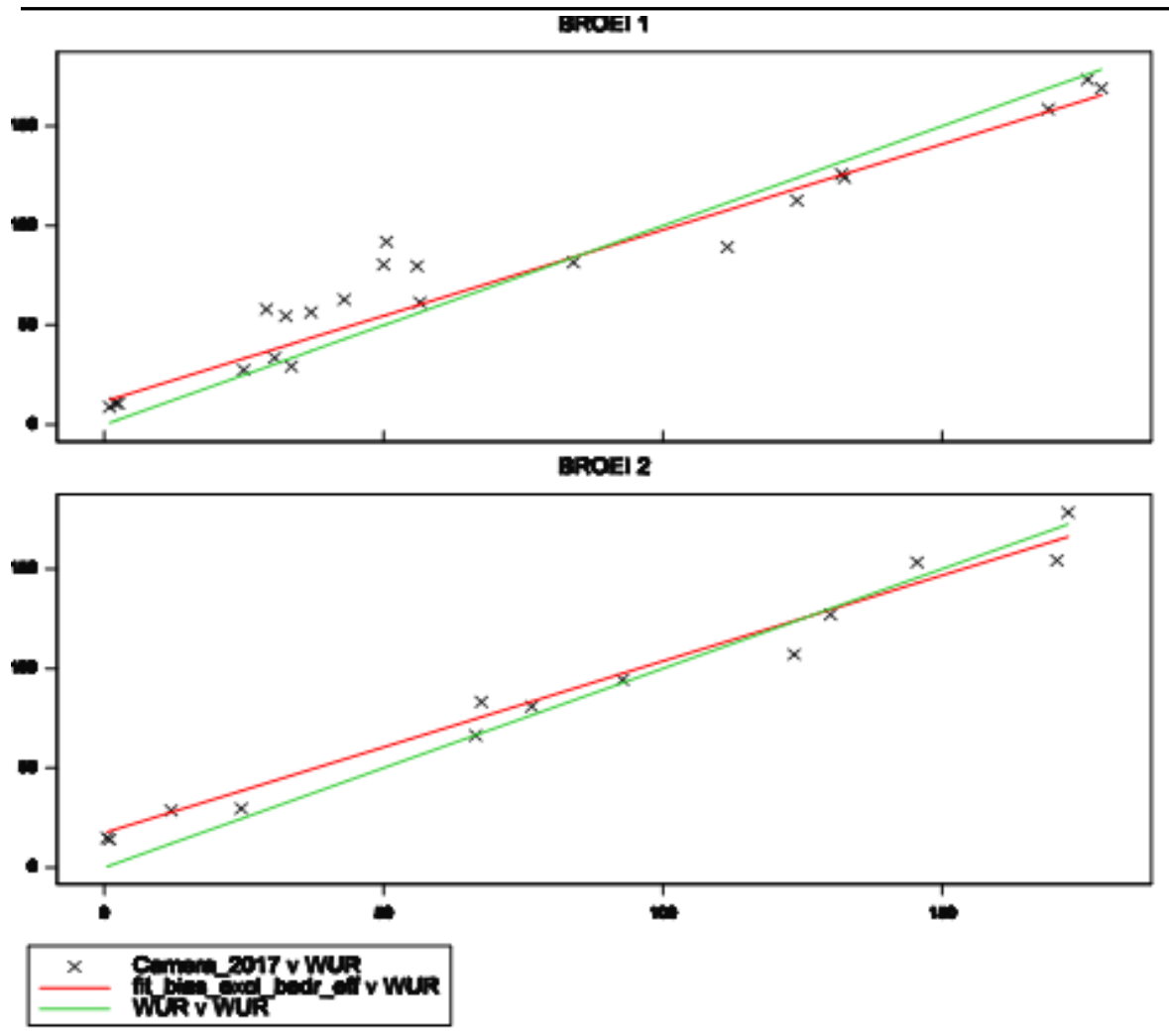

Figuur B11.1 Totaalscore_camera ( $y$-as) versus Totaalscore_referentie( $x$-as_per steekproef per broeiwijze (broei 1 =laagbroei; broei 2=hoogbroei); individuele waarnemingen (symbool $x$ ) en lijn $y=x$ (groen) en de bias-lijn (rood).

Tabel B11.2 Geschatte parameters voor additionele onnauwkeurigheid (random afwijking t.o.v. de referentie-totaalscore).

\begin{tabular}{lllc} 
& \multicolumn{1}{c}{ traject } & Variantiecomponent $\left(\mathrm{s}^{2}\right)$ & $2 \mathrm{~s}$ \\
Vleeskuiken-bedrijfseffecten & Totale traject & 65,41 & 16,2 \\
\hline Vleeskuiken-koppeleffecten & Totale traject & N.S. & N.S. \\
\hline Vleeskuiken- & Referentiescore: & $0,6 \mathrm{a}$ & 1,5 \\
steekproefeffecten & $0-9$ & $52,2 \mathrm{~b}$ & 14,4 \\
& $10-66$ & $62,8 \mathrm{~b}$ & 15,8 \\
& $67-132$ & $91,5 \mathrm{~b}$ & 19,1 \\
& $133-190$ & $*$ & $*$
\end{tabular}

In tabel B11.2 staat de geschatte onnauwkeurigheid, opgesplitst in een bedrijfseffect $(2 s=16,2)$ en een rest-steekproefonnauwkeurigheid. De rest-steekproefonnauwkeurigheid is significant lager bij lage referentiescores. Dit is logisch en volgt uit de aard van de score (minimum ligt bij 0 ). In het traject tussen referentietotaalscore 10 en 190 lijkt de rest-steekproefonnauwkeurigheid vergelijkbaar en wordt overal geschat op een gemiddelde van 16,5 (2s).

Al met al betekenen deze resultaten dat we een inschatting kunnen maken in welke traject de additionele onnauwkeurigheid van een individuele steekproef ligt.

Op herkomstbedrijven met een relatief hoog bedrijfseffect (bijvoorbeeld $+16,2$ ) kan een individuele steekproef dus een additionele (naast de bias) afwijking hebben van $+32,7$ punten.

Afwijkingen in deze orde van grootte zien we ook inderdaad in de ruwe waarnemingen terug op 1 van de herkomstbedrijven.

Uit deze beperkte validatie volgt de conclusie dat er bedrijfsgebonden afwijkingen bestaan bij de beoordeling van de camera. 


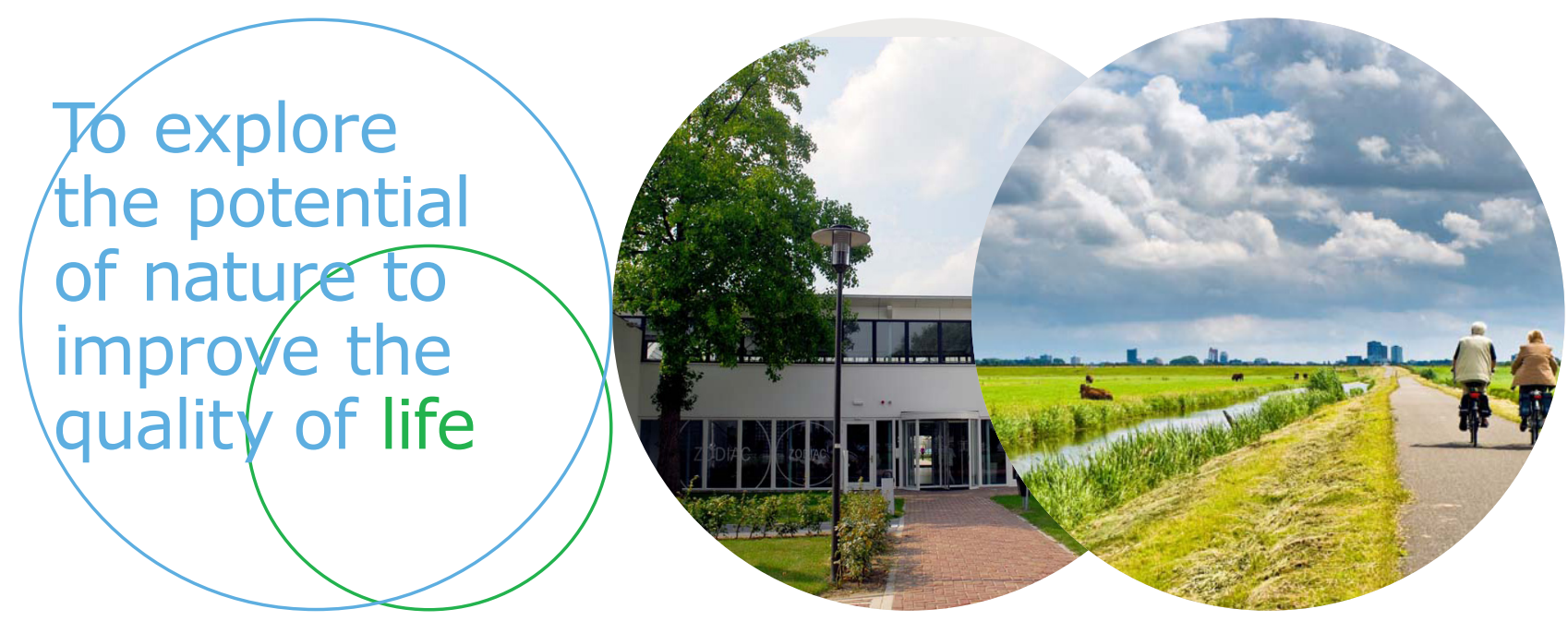

Wageningen Livestock Research Postbus 338

Wageningen Livestock Research ontwikkelt kennis voor een zorgvuldige en 6700 AH Wageningen

T 0317483953

renderende veehouderij, vertaalt deze naar praktijkgerichte oplossingen en innovaties, en zorgt voor doorstroming van deze kennis. Onze wetenschappelijke

E info.livestockresearch@wur.nl www.wur.nl/ livestock-research kennis op het gebied van veehouderijsystemen en van voeding, genetica, welzijn en milieu-impact van landbouwhuisdieren integreren we, samen met onze klanten, tot veehouderijconcepten voor de $21 \mathrm{e}$ eeuw.

De missie van Wageningen University \& Research is 'To explore the potential of nature to improve the quality of life'. Binnen Wageningen University \& Research bundelen 9 gespecialiseerde onderzoeksinstituten van Stichting Wageningen Research en Wageningen University hun krachten om bij te dragen aan de oplossing van belangrijke vragen in het domein van gezonde voeding en leefomgeving. Met ongeveer 30 vestigingen, 6.500 medewerkers en 10.000 studenten behoort Wageningen University \& Research wereldwijd tot de aansprekende kennisinstellingen binnen haar domein. De integrale benadering van de vraagstukken en de samenwerking tussen verschillende disciplines vormen het hart van de unieke Wageningen aanpak. 